\title{
Savunma Harcamaları ve Ekonomik Özgürlükler İlişkisi ${ }^{\star}$
}

\author{
The Relationship \\ between Defense Expenditures and Economic Freedoms
}

Mehmet Samet ERDEM $^{\star \star ~-~ S e l a m i ~ S E Z G I N ~}{ }^{\star \star \star}$

$\ddot{O} z$

Çalşsmada savunma harcamalar ile ekonomik özgürlükler arastndaki iliski Fraser Enstitüsü'nün ekonomik özgürlükler endeksinde yer alan 110 ülkenin 2000-2014 ynllar arasindaki verileri kullanılarak panel veri analizi yöntemiyle incelenmiştir. Analiz sonuçlarndan elde edilen bulgular, genel ekonomik özgürlük endeksi ve endeksin ana bileşenlerini oluşturan devletin faaliyet alanmin genişliği, hukuki yapr ve mülkiyet haklar, güçlü paraya erişim ve kredi, isgü̈ü ve iş dünyası konusunda yasal düzenlemelerin savunma harcamalar üzerinde anlaml ve negatif yönlü ilişkisinin olduğunu gösterirken, uluslararası ticaret serbestisi ana bileşeninin savunma harcamalar ile ilişkisine rastlanamamıştr.

Anahtar Kelimeler: Savunma Harcamalar, Ekonomik Özgürlükler, Ekonomik Özgürlük Endeksi, Ekonomik Büyüme, Panel Veri Analizi.

\section{Abstract}

This paper aimed to examine the relationship between defense expenditures and economic freedom for 110 countries from the Fraser Institute's Economic Freedoms Index, for the period of 2000-2014 by using panel data analysis. The results of the empirical analysis indicate that there is a significant and negative relationship between defense expenditures and an overall index of economic freedom, size of government, legal systems and property rights,

* $\mathrm{Bu}$ makale, yazarın doktora tezinin ilgili bölümünden oluşturulmuştur. Mehmet Samet Erdem, Savunma Ekonomisi Üzerine Üç Makale, Yayınlanmamış Doktora Tezi, Eskişehir Osmangazi Üniversitesi, Sosyal Bilimler Enstitüsü.

*夫 Dr. Öğr. Üyesi, Sinop Üniversitesi İktisadi ve İdari Bilimler Fakültesi, Sinop, Türkiye, ORCID: 0000-0001-7344-2166, mserdem@sinop.edu.tr.

${ }_{\star \star \star}$ Prof. Dr., Eskişehir Osmangazi Üniversitesi İktisadi ve İdari Bilimler Fakültesi, Eskişehir, Türkiye, ORCID: 0000-0002-4604-0601, selamisezgin@ogu.edu.tr.

Geliş Tarihi / Submitted: 07.10.2020

Kabul Tarihi / Accepted: 22.04.2021 
sound money and regulation of credit, labor, and business; but there is no significant relationship for freedom to trade internationally main-component of the index.

Keyzwords: Defense Expenditures, Economic Freedom, Economic Freedom Index, Economic Growth, Panel Data Analysis.

\section{Giriş}

Günümüz büyüme modellerine alternatif büyüme yaklaşımı arayışları, ülkeleri reformlara, kurumların yeniden inşasına, kendilerini yeniden gözden geçirmeye yöneltmektedir. Kısaca ekonomik özgürlükler diye ifade edilen söz konusu liberalizasyon süreci ülkeleri ekonomik büyümeye taşıyacak yollardan biri olarak görülmektedir.

Ekonomik özgürlükler ile savunma harcamalarının ilişkisi, ekonomik büyümedeki etkileri sebebiyle ortak bir paydada yer almaktadır. Bu ortak paydanın ekonominin temel sorunlarından biri olduğu düşünüldüğünde bu iki değişkenin arasındaki ilişkinin analiz edilmesi son derece önem kazanmaktadir.

Ekonomik büyümenin temelinde ekonomik özgürlüklerin olduğu, devletin bu noktadaki konumunun savunma, adalet ve belirli kamusal görevlerden oluştuğu görüşü çerçevesinde devletin rollerinin başında gelen savunmanın, ekonomik özgürlükleri oluşturan parametrelerle olan ilişkisini incelemek bu çalışmanın konusunu oluşturmaktadır.

Çalışmanın ilk bölümü savunma harcamaları-ekonomik özgürlükler arasındaki ilişkinin teorik çerçevesinden oluşmaktadır. Daha sonra konuyla ilgili literatür özetine yer verilerek analize ilişkin modeller ve veriler açıklanmıştır. Son olarak panel veri analizi yapılarak sonuçlar yorumlanmiştır.

\section{Savunma Harcamalar1-Ekonomik Özgürlükler İlişkisi}

1947-1992 yılları arasında Batı Bloğu ve Doğu Bloğu ülkeleri arasında meydana gelen ve Soğuk Savaş olarak nitelendirilen dönemin bitmesi, ülkeleri silahlı kuvvetlerini yeniden düzenleme ve modernizasyon gibi süreçlerine daha fazla eğilmesine yönlendirmiştir. Bu yönlendirmeyle beraber savunmaya ayrılan payın artması, ülkelerin savunma harcamalarında önemli ölçüde artışları da beraberinde getirmiştir. 
Savunma harcamaları üzerinde uzlaşılmış tanımı bulunmayan bir kavram olsa da genel olarak bir ülkenin belirli bir dönemde yaptığ kamu harcamalarından savunmaya ayırdığı pay ya da ülkenin ulusal güvenliğini sağlamak amacıyla yapılan harcamalar olarak da nitelendirilebilir. $\mathrm{Bu}$ bağlamda bir harcama kalemi olarak gelir ile olan ilişkisi kaçınılmaz olmakta ve ekonomik büyümenin bu ilişkinin temelinde olduğu düşüncesi önem kazanmaktadır.

Ekonomik büyümeye nelerin neden olduğu, kuşkusuz ekonominin en önemli sorularından birini oluşturur. Bu soruya cevap aranan tarihsel sürecin başlarına gittiğimizde, Adam Smith ekonomik büyümenin nedenlerini sorguladığı "Ulusların Zenginliğinin Doğası ve Nedenleri Üzerine Bir İnceleme" adlı eserinde serbest piyasayla, özel mülkiyetle ve minimum devlet müdahalesiyle refaha ulaşılacağını bir başka ifadeyle ekonomik özgürlüklerin ekonomik büyümeye yol açacağını belirtmiştir.

18. yüzyıldan başlayarak 20. yüzyıla kadar etkili olan liberal düşünce, büyük buhranla beraber devletin ekonomideki görevlerini yeniden tanımlayan Keynesyen iktisada hâkimiyetini bırakmış olsa da günümüzde ekonomik özgürlüklerin, reformların ve liberalizasyonun ekonomik büyümenin temeli olduğu düşüncesi farklı düşünce sistemlerinin süreç içerisinde gelişmesiyle de gün geçtikçe önem kazanmaktadır.

Ekonomik özgürlükler ile ilgili Adam Smith’ten günümüze ortak bir tanımlama yapılmamasına karşılık en geniş tanım Miller ve Kim (2011) tarafından yapılmıştır. Buna göre ekonomik özgürlük: "Mallarn ve hizmetlerin üretim, dağttm veya tüketiminin tüm özgürlüklerini ve haklarm kapsamalıdrr. Ekonomik özgürlüklerin en yüksek biçimi mutlak mülkiyet hakkın, emek, sermaye ve mallarm serbest dolaşımın, ekonomik bağımsıllk üzerindeki baskı ya da kısttlamalarn bireyin özgürlüğ̈̈nü koruması ve sürdürmesi için zorunlu olandan fazla olmamasın kapsamalıdı" biçiminde tanımlanırken, belirtilmek istenen "ekonomik olarak özgür bir toplumda, bireyler kanunlar çerçevesinde istedikleri biçimde çalısma, üretme, tüketme ve yatrrm yapma konusunda özgür ve yetkili olmalı ve bu özgürlüklerin devlet tarafindan korunmalı" olduğudur. ${ }^{1}$

${ }^{1}$ Terry Miller and Kim R. Holmes, 2011 Index of Economic Freedom, The Heritage Foundation, The Wall Street Journal, New York, NY 10281, 2011, p. 20. 
Ekonomik özgürlükler çerçevesinde devlete biçilen rol, söz konusu özgürlüklerin korunmasının yanında, devletin başlıca diğer faaliyetlerini de içerir. Adam Smith, hem uygar hem de ilkel devletlerin 3 temel özelliğini savunma, adalet ve kamu işleri olarak sıralamıştır. Toplumun gelişmişlik düzeyine göre farklılık gösterse de bu 3 temel aynı zamanda kamu hizmetini de oluşturur.

Savunmayı devletin birincil görevi olarak tanımlayan Smith, topluluğu diğer bağımsız topluluklardan koruyacak olan askerî kuvvetin hem barış zamanında hazır olmasının hem de savaş zamanında kullanılmasının farklı masraflarla gerçekleşeceğini belirtmiştir. Topluluk uygarlık yolunda ilerlediği sürece, topluluğu savunmanın özellikle savaş sonrasında ve barış dönemlerinde daha da masraflı olacağını belirtmiştir. ${ }^{2}$

Devletin ikincil görevi olan adaleti, topluluğun her üyesini bir başka üye tarafından ezilmesinden ve haksızlığa uğramasından korumak olarak tanımlamıştır. $\mathrm{Bu}$ işlev de savunma gibi bir masraf oluşturur ve bu masraf bireylerden değil devletin gelirlerinden karşılanmalıdır. Mülkiyet haklarını savunmak ve korumak, mülkiyet büyüdükçe eşitsizliğin büyümesi nedeniyle daha da zorlaşır ya da masraflı hale gelir. Yargı içerisinde yer alan adaletsizliğin ve yolsuzlukların önüne geçebilmek için öncesinde adalet hizmeti için başvuranlardan alınan gelir sonrasında devlet tarafından karşılanarak bir kamu hizmetine dönüşmüştür. Bir başka masrafı ifade eden bu değişim dış tehditlere karşı sürekli artan giderlerin daha da artmasına neden olmuştur. ${ }^{3}$

Kamu işleri ve kurumları olan devletin son amacı olan toplumun ticaretini oluşturmak ve halkı eğitmek görevi savunma ve adalet önceliklerinden sonra gelir. Adam Smith, ticari çıkarların ne savaş ne de barış amaçlarına ihtiyaç duymadan kendi başına var olacağını bunu da elçilikler vasıtasıyla yapılacağını belirtmiştir. Ticaret yollarının ve tüccarların güvenliği için de önemli görülen yerlere garnizonlar yapılması gerektiğinin altını çizerek bunun da bir masraf doğurduğunu ifade etmiştir. ${ }^{4}$

\footnotetext{
${ }^{2}$ Adam Smith, The Wealth of Nations, Wordsworth Edition, London, 2012, p. 708-721.

${ }^{3}$ Ibid.

${ }^{4}$ Smith, Ibid. p. 722-758.
} 
Klasik düşüncenin temel dinamiklerinde yükselen ekonomik özgürlüklerin büyümeyi sağlayacağı düşüncesi, aynı yıllarda Kant (1795) tarafından da demokrasinin, ekonomik dayanışmanın ve uluslararası hukukun sürekli barışın temellerini oluşturacağı görüşüyle de biçimlenmiştir. ${ }^{5}$ Sonraki yıllarda Schumpeter (1919), endüstrileşmiş kapitalist üretim tarzına geçişin eyaletler arası savaşı giderek ortadan kaldıracağını belirterek ekonomik özgürlükler ile çatışma arasındaki bağı ifade etmiştir. ${ }^{6}$

1960'lı yıllarda Solow tarafindan temelleri atılan Neoklasik düşüncenin büyüme reçeteleri, 1980'li yıllara kadar etkili olmuştur. 1986 yılında Romer tarafından geliştirilen içsel büyüme teorisi ile uzun dönemli büyümeye cevap aranmıştır. İçsel büyüme teorilerine göre uzun soluklu sürekli büyümenin temeli sermaye birikimi, devleti küçültmek, ekonomiyi dış ticaret ve yabancı yatırımlara açmak, mülkiyet haklarına ve hukukun üstünlüğüne riayet etmek, regülasyonlar ve kontrollerle verimli sektörlere ağır yükler yüklememek, beşeri sermayeye yönelik yatırımlar yapmak olarak belirlenmiştir. ${ }^{7}$

Devlete biçilen rolün keskin sınırlarla çizilmesine karşın, ekonomik özgürlük kavramının soyut bir kavram olması 1990’lı yıllara kadar sürmüştür. $\mathrm{Bu}$ yıllarda çeşitli enstitülerin endeksleme çalışmalarıyla beraber ekonomik özgürlükler rakamsal olarak ifade edilerek sıralanmaya başlanmıştır. Çeşitli büyüme modelleriyle ekonomik büyümeye cevap aranma serüveninde her dönem tartısma konusu olan savunma harcamaları, ekonomik büyümenin nedenleri sorusunda kendine olumlu ya da olumsuz olarak daima yer bulmuştur. $\mathrm{Bu}$ çerçevede savunma harcamalarının ekonomik özgürlükler ile olan ilişkisinin incelenmesi ile tartışmalara farklı bir açıdan bakılarak katkı sağlanabilecektir.

\footnotetext{
${ }^{5}$ Immanuel Kant, Perpetual Peace: A Philosophical Essay, Cambridge University Press, Cambridge, 1795, Vol. 1903.

${ }^{6}$ Joseph A. Schumpeter, The Sociology of Imperialism, In Imperialism \& Social Classes, 3-98 Cleveland, World Publishing, 1919.

${ }^{7}$ William W. Beach and Gareth Davis, The Index Of Economic Freedom And Economic Growth, The Heritage Foundation, Washington, 1997, p. 4-5.
} 


\section{Savunma Harcamaları ve Ekonomik Özgürlükler Üzerine Yapılan Çalışmalar}

Rummel (1983), sosyal alan teorisine dayandırdığ 1976-1980 yıllarını kapsayan 5 yıllık süreç için liberterizmin ülke dışı şiddetle ilişkisini inceleyerek, daha az özgürlüğe sahip ülkelerin daha çok şiddete başvurduğu sonucuna ulaşmıştır. Liberterizm politik özgürlük ya da özgürlük olarak tanımlandığında sonucun büyük ölçüde desteklediğini belirterek ekonomik özgürlüklere sivil özgürlükler ve politik haklar eklendiğinde şiddetin anlamlı ölçüde azaldığını belirtmiştir. ${ }^{8}$

Rosh (1988), 63 üçüncü dünya ülkesinin askerî harcamalarını 1969-1978 yılları arasında inceleyerek güvenlik ağı kavramının ve ülkenin politik sürecindeki biçimin askerî harcamalar üzerinde önemli bir yeri olduğunu belirtmiştir. Demokratik süreçteki ülkelerin kaynaklarını daha az askerî harcamalara ayırdıklarını, ülkeler demokrasiden uzaklaştıkça bu payın hızlı bir artış gösterdiğini ifade etmiştir. ${ }^{9}$

Barbieri (1996), ticaretin eyaletler arası barış için bir yol olabileceği düşüncesine dayandırdığı, 1870-1938 yıllarını kapsayan çalışmasında ticaretin çatışmayı engellemediği sonucuna ulaşmıştır. Bunun yanında, kapsamlı ekonomik bağımlılığın askerî tartışmalara girme olasılığını arttırmasına karşın, savaşın görülme sıklığı üzerinde az da olsa etkili olduğunu belirtmiştir. ${ }^{10}$

Tures (2003), ekonomik özgürlük ve çatışma arasındaki ilişkiyi, Dünya Ekonomik Özgürlük Endeksini kullanarak ülkelerin sıralamasına göre iç savaş arasındaki bağlantıyı kurarak incelemiştir. Ekonomik özgürlüklerin çatışmayı azalttığı yönünde güçlü bağlar bularak özgür ülkelerin genellikle daha az çatışma ve savaş içinde bulunduğunu, kısmen özgür ülkelerin özgür ülkelere göre daha çok iç çatışma yaşadığını, özgür

\footnotetext{
${ }^{8}$ Rudolph. J. Rummel, “Libertarianism and International Violence”, fournal of Conflict Resolution, 1983, 27(1), p. 27-71.

${ }^{9}$ Robert. M. Rosh, "Third World Militarization: Security Webs and the States They Ensnare", Fournal of Conflict Resolution, 1988, 32(4), p. 671-698.

${ }^{10}$ Katherine Barbieri, "Economic Interdependence: A Path to Peace or a Source of Interstate Conflict?”, Fournal of Peace Research, 1996. 33(1), p. 29-49.
} 
olmayan ülkelerin ise savaş ve çatışma ile çok daha fazla bağı olduğunu ifade ederek, ekonomik özgürlüklerin barışı sağladığı sonucuna varmıştır. ${ }^{11}$

Ekonomik özgürlüklerin savunma ekonomisi açısından önemini barışın sağlanması açısından ele alan Gartzke (2005), ülke içinde piyasayı endişeye düşürecek hareketlerin yatırımları azaltarak ekonomiyi aşağıya çekme yönünde bir etki yaratacağını, ülke dışında güç kullanılmasının ise genellikle yurtiçi yatırımlarda bir gerileme ve sermayenin yurt dışına çıkması ile ilişkilendirileceğini belirtmiştir. Bir başka açıdan savunma harcamalarının işgal için kullanımında ortaya çıkan işgücü ve kaynak maliyetinin sürekli artış göstermesiyle ekonomik özgürlüklerin çatışmayı engellemesi gerektiğini öne sürse de bu durumun uluslararası politika ve iç rejimlerin sürdürülmesi konusunda çok büyük etkilere sahip olmayacağını ifade etmiştir. ${ }^{12}$

Looney ve McNab (2008), ekonomik liberalizasyon ve geliştirilmiş yönetimin savunma-büyüme arasındaki değiş-tokuş dengesini değiştirip değiştirmediğini analiz ettikleri çalışmalarında, reformların kilit kombinasyonlarının ve yönetişim önlemlerinin savunma harcamaları ile ilişkilendirilen birçok olumsuz ekonomik etkinin etkisiz hale gelmesinde büyük ölçüde etkili olduğu sonucuna varmışlardır. ${ }^{13}$

Ylldırım ve Sezgin (2005), savunma harcamaları ve demokrasinin derecesi arasında negatif bir ilişkinin olup olmadığını 1987-1997 yıllarını kapsayan 92 ülkeyi kesit ve panel veri analizi kullanarak incelemişlerdir. Demokrasi endeksinin bileşenlerinin politik haklar, insan hakları ve özgürlük statüsü olarak ele alındığ çalışmada daha yüksek demokrasi seviyesinde olan ülkelerin daha düşük savunma harcamaları olduğunu belirtmişlerdir. ${ }^{14}$

${ }^{11}$ John A. Tures, "Economic Freedom and Conflict Reduction: Evidence from the 1970s, 1980s, and 1990s", Cato Fournal, 2002, 22(3), p. 533-542.

${ }^{12}$ Erik Gartzke, "Economic Freedom of the World 2005", Annual Report, The Fraser Institute, Vancouver, Canada, 2005.

${ }^{13}$ Robert Looney and Robert. M. Mcnab, "Can Economic Liberalization and Improved Governance Alter the Defense-Growth Trade-Off?", Review of Financial Economics, 2008, 17(3), p. 172-182.

${ }^{14}$ Julide Y1ldırım and Selami Sezgin, "Democracy and Military Expenditure: A CrossCountry Evidence”, Transition Studies Review, 2005, 12(1), p. 93-100. 
Dzidrov vd. (2013), ekonomik özgürlük ve çatışma arasındaki ilişkiyi, Balkan bölgesindeki 8 ülkede 1995-2012 yılları arasında Heritage Vakfı'nın verilerini kullanarak incelemiş, Balkan ülkelerinin daha az çatışma ile ekonomik olarak özgür ülkeler olma eğiliminde oldukları sonucuna varmışlardır. ${ }^{15}$

Literatürdeki çalışmalara bakıldığı zaman liberalizasyon ve savunma harcamaları ilişkisinin demokrasi, ekonomik özgürlükler endeks puanı ve/veya az sayıda endeks değişkeni baz alınarak incelendiği görülmüştür. Bunun yanı sıra ekonomik özgürlüklere ilişkin birçok çalışma mevcuttur. Genellikle ekonomik özgürlüklerin ekonomik büyüme ile olan ilişkisinin incelendiği bu çalışmaların bir kısmına Tablo l'de yer verilmiştir.

\section{Tablo 1: Ekonomik Özgürlükler Üzerine Yapılan Çalışmalar}

\begin{tabular}{|c|c|c|c|c|c|}
\hline $\begin{array}{l}\text { Çalışma- } \\
\text { nin Yili }\end{array}$ & Yazar(lar) & $\begin{array}{l}\text { Dönem, } \\
\text { Ülke ve } \\
\text { Model }\end{array}$ & Yöntem & Veri & Ana Sonuçlar \\
\hline 1996 & Barro $^{16}$ & $\begin{array}{c}1960-1990, \\
100 \text { Ülke. }\end{array}$ & $\begin{array}{l}\text { Panel veri } \\
\text { analizi. }\end{array}$ & $\begin{array}{l}\text { Gastil, Barro- } \\
\text { Lee Veri seti, } \\
\text { Summers- } \\
\text { Heston Veri Seti. }\end{array}$ & $\begin{array}{c}\text { Demokrasinin büyüme } \\
\text { üzerindeki genel etkisi } \\
\text { zayıftır. }\end{array}$ \\
\hline 1998 & $\begin{array}{l}\text { Nelson ve } \\
\text { Singh }^{17}\end{array}$ & $\begin{array}{c}\text { Klasik ve } \\
\text { Genişletilmiş } \\
\text { Büyüme } \\
\text { Modeli, } \\
\text { 1970-1989, } \\
67 \text { Gelişmekte } \\
\text { olan ülke. }\end{array}$ & $\begin{array}{l}\text { Panel veri } \\
\text { analizi. }\end{array}$ & $\begin{array}{l}\text { Gastil, Easton } \\
\text { ve Walker, } \\
\text { IMF, Dünya } \\
\text { Bankası. }\end{array}$ & $\begin{array}{l}\text { Demokrasi ve politik } \\
\text { özgürlüklerde meydana } \\
\text { gelen düşüş, ülkelerin } \\
\text { ekonomik } \\
\text { performanslarını da } \\
\text { ciddi olarak } \\
\text { etkilemektedir. }\end{array}$ \\
\hline 1999 & $\begin{array}{c}\text { Gwartney, } \\
\text { Lawson ve } \\
\text { Holcombe }^{18}\end{array}$ & $\begin{array}{l}\text { 1975-1995, } \\
82 \text { Ülke. }\end{array}$ & $\begin{array}{l}\text { Panel veri } \\
\text { analizi. }\end{array}$ & $\begin{array}{c}\text { Fraser } \\
\text { Institute. }\end{array}$ & $\begin{array}{l}\text { Ekonomik özgürlükler } \\
\text { ekonomik büyümenin } \\
\text { önemli bir belirleyicisidir. }\end{array}$ \\
\hline
\end{tabular}

${ }^{15}$ Misko Dzidrov, Dejan Mirakopcski et al. "Relationship between Economic Freedom and Conflict in the Balkan Region" International fournal of Scientific E Engineering Research, 2013, 4(10), p. 433-436.

${ }^{16}$ Robert. J. Barro," Democracy and Growth”, Fournal of Economic Growth, 1996, 1(1), p. 1-27.

${ }^{17}$ Michael. A. Nelson and Ram. D. Singh, "Democracy, Economic Freedom, Fiscal Policy, and Growth in LDCs: A Fresh Look", Economic Development and Cultural Change, 1998, 46(4), p. 677-696.

18 James. D. Gwartney, Robert. A. Lawson et al. "Economic Freedom and the Environment for Economic Growth", Fournal of Institutional and Theoretical Economics (FITE)/Zeitschrift für die gesamte Staatswissenschaft, 1999, 155(4), p. 643-663. 


\begin{tabular}{|c|c|c|c|c|c|}
\hline 2002 & $\begin{array}{l}\text { Carlsson ve } \\
\text { Lundström }^{19}\end{array}$ & $\begin{array}{l}1975-1995, \\
74 \text { Ülke, } \\
\text { Ekonomik } \\
\text { Özgürlük } \\
\text { Modeli. }\end{array}$ & $\begin{array}{l}\text { Panel veri } \\
\text { analizi. }\end{array}$ & $\begin{array}{c}\text { Fraser Institute } \\
2000 \text { Yılı } \\
\text { Dünya } \\
\text { ekonomik } \\
\text { Özgürlük } \\
\text { Raporu, } \\
\text { Dünya Bankası. }\end{array}$ & $\begin{array}{c}\text { Ekonomik özgürlük } \\
\text { ekonomik büyüme için } \\
\text { önemlidir. } \\
\text { Bazı kategoriler } \\
\text { endekste önemsizken } \\
\text { bazıları da büyüme } \\
\text { üzerinde negatif etkiye } \\
\text { sahiptir. }\end{array}$ \\
\hline 2012 & $\begin{array}{l}\text { Fabro ve } \\
\text { Aixala }^{20}\end{array}$ & $\begin{array}{l}\text { 1976-2005, } 79 \\
\text { Ülke, Eş- } \\
\text { zamanli } \\
\text { Denklemler } \\
\text { Modeli. }\end{array}$ & $\begin{array}{l}\text { Panel veri } \\
\text { analizi ve } \\
\text { iki } \\
\text { aşamalı } \\
\text { en küçük } \\
\text { kareler } \\
\text { yöntemi. }\end{array}$ & $\begin{array}{c}\text { Freedom } \\
\text { House ve } \\
\text { Fraser } \\
\text { Institute, } \\
\text { Dünya Bankası. }\end{array}$ & $\begin{array}{l}\text { Ekonomik özgürlük, } \\
\text { insan hakları ve siyasi } \\
\text { haklar ekonomik } \\
\text { büyüme için önemlidir. }\end{array}$ \\
\hline 2013 & $\begin{array}{c}\text { Erdal ve } \\
\text { Yenipazarlı }^{21}\end{array}$ & $\begin{array}{l}\text { 1970-2006, } \\
\text { Türkiye, } \\
\text { Klasik } \\
\text { Büyüme } \\
\text { Modeli. }\end{array}$ & $\begin{array}{l}\text { Zaman } \\
\text { serisi } \\
\text { analizi. }\end{array}$ & $\begin{array}{c}\text { Heritage } \\
\text { Foundation } \\
\text { ve Fraser } \\
\text { Institute, } \\
\text { TCMB, TÜ̇̇K. }\end{array}$ & $\begin{array}{l}\text { Ekonomik büyüme ve } \\
\text { ekonomik özgürlük } \\
\text { arasındaki ilişki, } \\
\text { kullanılan tekniğe ve } \\
\text { göstergelere göre } \\
\text { farklılıklar } \\
\text { göstermektedir. }\end{array}$ \\
\hline 2013 & $\begin{array}{l}\text { Cebula, } \\
\text { Clark ve } \\
\text { Mixon }^{22}\end{array}$ & $\begin{array}{l}\text { Seçmeli } \\
\text { Ekonomik } \\
\text { Özgürlük } \\
\text { Modeli, } \\
\text { 2002-2006, } \\
\text { OECD } \\
\text { Ülkeleri. }\end{array}$ & $\begin{array}{l}\text { Panel veri } \\
\text { analizi; } \\
\text { sabit } \\
\text { etkili } \\
\text { en küçük } \\
\text { kareler } \\
\text { eşitliği. }\end{array}$ & $\begin{array}{c}\text { Heritage } \\
\text { Foundation, } \\
\text { IMF, OECD. }\end{array}$ & $\begin{array}{l}\text { İş özgürlüğü, yolsuzluktan } \\
\text { bağımsızllk, yatırım } \\
\text { özgürlüğü, parasal } \\
\text { özgürlük, sınırlı devlet, } \\
\text { ticaret özgürlüğü ve } \\
\text { mülkiyet haklarının } \\
\text { özgürlüğündeki yüksek } \\
\text { düzeyler ekonomik büyüme } \\
\text { üzerinde istatistiksel olarak } \\
\text { anlamlı etki yaratırken, } \\
\text { işgücü özgürlügüü, finansal } \\
\text { özgürlük ve mali özgürlük } \\
\text { istatistiksel olarak anlamlı } \\
\text { değildir. }\end{array}$ \\
\hline
\end{tabular}

19 Fredrik Carlsson and Susanna Lundström, "Economic Freedom and Growth: Decomposing the Effects", Public Choice, 2002, 112(3-4), p. 335-344.

${ }^{20}$ Gema Fabro and Jose Aixalá, "Direct and Indirect Effects of Economic and Political Freedom on Economic Growth", Fournal of Economic Issues, 2012, 46(4), p. 1059-1080.

${ }^{21}$ Fuat Erdal and Asli Yenipazarl," Which Economic Freedoms Contribute Income Per Capita? Are Results Sensitive to the Indicators and the Estimation Methods?", Emerging Markets Finance and Trade, 2013, 49(5), p. 130-147.

${ }^{22}$ Richard. J. Cebula, J. R. Clark et al.," The Impact of Economic Freedom on Per Capita Real GDP: A Study of OECD Nations”, fournal of Regional Analysis E Policy, 2013, 43(1), p. 34-41. 


\begin{tabular}{|c|c|c|c|c|c|}
\hline 2014 & $\begin{array}{c}\text { Panahi, } \\
\text { Assadzadeh } \\
\text { ve Refaei }^{23}\end{array}$ & $\begin{array}{c}\text { Genel } \\
\text { Ekonomik } \\
\text { Özgürlük } \\
\text { Modeli, } \\
\text { 2000-2009, } \\
13 \text { Orta doğu } \\
\text { ve Kuzey } \\
\text { Afrika } \\
\text { Ülkesi. }\end{array}$ & $\begin{array}{l}\text { Panel veri } \\
\text { analizi. }\end{array}$ & $\begin{array}{c}\text { Fraser } \\
\text { Institute. }\end{array}$ & $\begin{array}{l}\text { Ekonomik özgürlüğün } \\
\text { ekonomik büyüme } \\
\text { üzerinde önemli bir } \\
\text { etkisi vardır, fakat } \\
\text { ekonomik özgürlüğün } \\
\text { bütün alanları aynı } \\
\text { biçimde etkili değildir. }\end{array}$ \\
\hline 2016 & $\begin{array}{c}\text { Saunoriz ve } \\
\text { Sajny }^{24}\end{array}$ & $\begin{array}{l}\text { Genel } \\
\text { Ekonomik } \\
\text { Özgürlük } \\
\text { Modeli, } \\
\text { 2001-2010, } \\
61 \text { Ülke } \\
\end{array}$ & $\begin{array}{c}\text { İki } \\
\text { aşamalı } \\
\text { en küçük } \\
\text { kareler } \\
\text { yöntemi. }\end{array}$ & $\begin{array}{c}\text { Heritage } \\
\text { Foundation, } \\
\text { Birleşmiş } \\
\text { Milletler. }\end{array}$ & $\begin{array}{l}\text { Ekonomik özgürlükler } \\
\text { resmî girişimciliği } \\
\text { teşvik ederken } \\
\text { kayıt dışı girişimciliği } \\
\text { engellemektedir. }\end{array}$ \\
\hline 2016 & $\begin{array}{l}\text { Moreno ve } \\
\text { Guerrero }\end{array}$ & $\begin{array}{l}\text { Panel Veri } \\
\text { Modeli, } \\
\text { 2000-2010, } \\
\text { AB-28. }\end{array}$ & $\begin{array}{l}\text { Panel veri } \\
\text { analizi; } \\
\text { sabit } \\
\text { etkili } \\
\text { regresyon. }\end{array}$ & $\begin{array}{c}\text { Fraser } \\
\text { Institute, } \\
\text { EUROSTAT. }\end{array}$ & $\begin{array}{l}\text { Ekonomik özgürlük } \\
\text { ile gelir eşitsizliği } \\
\text { arasında kuvvetli bir } \\
\text { ilişki vardır fakat } \\
\text { ekonomik özgürlüğün } \\
\text { bütün alanları aynı } \\
\text { biçimde etkili değildir. }\end{array}$ \\
\hline
\end{tabular}

Kaynak: Yazar tarafından derlenmiştir.

\section{Yöntem}

Ridderstedt (2014), girişimcilik ve ekonomik özgürlükler arasındaki ilişkiyi 4 modele ayırarak incelemiştir. Ekonomik özgürlükler endeksini ve endeksin seçilen alt başlıklarını iki farklı girişimcilik tanımıyla ayrı ayrı analiz ederken aşağıda yer alan (1) modeli kullanmıştır: ${ }^{26}$

$$
\begin{aligned}
L O P P E A= & \alpha+\beta_{1} \operatorname{PrR}+\beta_{2} \operatorname{Reg}+\beta_{3} G S I Z E+\beta_{4} \operatorname{Tax}+\beta_{5} \text { Open }+\beta_{6} G D P_{P C}+ \\
& \beta_{7} A G E+\beta_{8} G R O W T H+\varepsilon
\end{aligned}
$$

\footnotetext{
${ }^{23}$ Hossein Panahi, Ahmad. Assadzadeh et al., "Economic Freedom and Economic Growth in MENA Countries", Asian Economic and Financial Review, 2014, 4(1), 105-116.

${ }^{24}$ James. W. Saunoris and Aishath Sajny, "Entrepreneurship and Economic Freedom: Cross-Country Evidence from Formal and Informal Sectors", Entrepreneurship E Regional Development, 2017, 29(3-4), p. 292-316.

${ }^{25}$ Salvador Pérez-Moreno and Maria. J. Angulo-Guerrero, "Does Economic Freedom Increase Income Inequality? Evidence from The EU Countries", fournal of Economic Policy Reform, 2016, 19(4), p. 327-347.

${ }^{26}$ Ivan Ridderstedt, Economic Freedom and Entrepreneurship: Conflicting Evidence, Bachelor Thesis, Södertörn University School of Social Sciences, Stockholm, 2014.
} 
Modelde, girişimciliğe ait bağımlı değişkenin logaritması alınarak (LOPPEA), bağımsız değişkenler içerisinde yer alan endeksin ana bileşenleri (Reg, GSIZE, Tax, Open) kontrol değişkenleri ile birlikte analiz edilmiştir. Kişi başı GSYH (GDP ${ }_{\mathrm{PC}}$ ), yaş bağımlılığı oranı (AGE) ve GSYH büyüme oranı (GROWTH) kontrol değişkeni olarak seçilmiştir.

Panahi, Assadzadeh ve Refaei (2014), ekonomik özgürlük ve ekonomik büyüme arasındaki ilişkiyi iki ayrı bölüm ve 6 ayrı modelde incelemiştir. İlk model genel ekonomik özgürlükler endeksi ile büyüme arasındaki ilişkiye aittir. Daha sonra kontrol değişkenlerini teker teker modele dâhil ederek ilk bölümde toplamda 5 model incelemiştir. Literatüre uygun olarak seçildiği belirtilen modeller:

$$
\begin{aligned}
L R G D P_{P C}= & \beta_{0} \beta L E C F R+\beta_{i} \sum L Z_{i}+\varepsilon_{i} \\
L R G D P_{i t}= & \alpha_{0}+\alpha_{1} L I N V_{i t}+\beta_{1} L S I Z_{i t}+\beta_{2} L P R O_{i t}+\beta_{3} L S M_{i t}+ \\
& \beta_{4} L F T R_{i t}+\beta_{5} L L O W_{i t}+\varepsilon_{i}
\end{aligned}
$$

şeklinde tanımlamıştır. ${ }^{27}$ Modellerdeki bütün bağımlı ve bağımsız değişkenler logaritmaları alınarak eşitliğe dâhil edilmiştir. Ekonomik büyümeyi temsilen kullanılan bağımlı değişken dolar cinsinden kişi başı reel GSYH (LRGDP), bağımsız değişken genel ekonomik özgürlükler endeksi (LECFR) ve kontrol değişkenleri (LZ) de kamu harcamalarının GSYH içerisindeki payı, yatırımların GSYH içerisindeki payı, nüfustaki büyüme oranı, ilkokula kayıt ve enflasyon oranından oluşmaktadır.

Çalışmasının ikinci bölümünde, ekonomik özgürlük endeksine ait 5 ana endeks ile büyüme arasındaki ilişkiyi (3) numaralı eşitlikte yer alan tek bir model ile incelemiştir. Modelde bağımlı değişken aynı kalmakta, bunun yanında bağımsız değişkenler endeks ana bileşenleri (LINV, LSIZ, LPRO, LSM, LFTR, LLOW) olarak değişmektedir ve çalışmada belirtilmese de modelin atıf yapıldığı Carlsson ve Lundrstrom (2000), model içerisinde yer alan yatırımların büyüme regresyonlarında önemli olduğunu ve bu tip modellerde sıklıkla kullanıldığını belirtmişlerdir. ${ }^{28}$

\footnotetext{
${ }^{27}$ Panahi, Ibid.

${ }^{28}$ Carlsson and Lundrstrom, Ibid.
} 
$\mathrm{Bu}$ çalışmada, ekonomik özgürlüklere ait endeks verileri ve bu verileri oluşturan ana başlıkların savunma harcamaları ile olan ilişkisi kontrol değişkenleri ile birlikte tahmin edilmiştir. Çalışmadaki modeller literatüre (Ridderstedt ${ }^{29}$ (2014), Panahi, ${ }^{30}$ vd. (2014) ve Carlsson ve Lundrstrom $^{31}$ (2000), Cebula ${ }^{32}$ (2013), Nelson ve Singh $^{33}$ (1998)) uygun olarak seçilmiştir. Bu kapsamda incelemede 2 ana model kullanılacaktır.

İlk modelde ekonomik özgürlükler ile savunma harcamaları arasındaki ilişki kontrol değişkenleri ile beraber incelenecektir. $\mathrm{Bu}$ bağlamda logaritması alınmış değişkenlerden savunma harcamalarının GSYH içerisindeki yüzdesi (LSH) bağımlı değişkeni, genel ekonomik özgürlük endeksi puanı (LEO) bağımsız değişken, GSYH büyüme oranı (LGBO), nüfusun büyüme hızı (LNBH) ve enflasyon büyüme oranı (LENF) kontrol değişkenlerini, $\beta_{0}$ sabit terimi ve $\mathrm{e}_{\mathrm{it}}$ hata terimini ifade etmektedir. $\mathrm{Bu}$ çerçevede oluşturulmuş model eşitlik (4)'te gösterilmiştir.

$$
L S H_{i t}=\beta_{0}+\beta_{1} L E O_{i t}+\beta_{2} L G B O_{i t}+\beta_{3} L N B H_{i t}+\beta_{4} L E N F_{i t}+e_{i t}
$$

İkinci modelde ekonomik özgürlük endeksini oluşturan 5 ana bileşenin savunma harcamaları ile olan ilişkisi kontrol değişkenleri ile beraber incelenecektir. Modeldeki bütün değişkenlerin logaritması alınmış olup modelin bağımlı değişkeni savunma harcamalarının GSYH içerisindeki yüzdesi (LSH); bağımsız değişkenleri Devletin Genişliği (LDG), Mülkiyet Hakları (LMH), Güçlü Para (LGP), Uluslararası Ticaret (LUT), Yasal Düzenlemeler (LYD); kontrol değişkenleri, GSYH büyüme oranı (LGBO), Nüfusun Büyüme Hızı (LNBH) ve Enflasyon Büyüme Oranıdır (LENF). $\beta_{0}$ sabit terimi ve $e_{i t}$ hata terimini ifade etmektedir. İkinci modele ilişkin denklem eşitlik (5)'te gösterilmiştir.

$$
\begin{aligned}
L S H_{i t}= & \beta_{0}+\beta_{1} L D G_{i t}+\beta_{2} L M H_{i t}+\beta_{3} L G P_{i t}+\beta_{4} L U T_{i t}+\beta_{5} L Y D_{i t}+ \\
& \beta_{6} L G B O_{i t}+\beta_{7} L N B H_{i t}+\beta_{8} L E N F_{i t}+e_{i t}
\end{aligned}
$$

\footnotetext{
${ }^{29}$ Ridderstedt, Ibid.

${ }^{30}$ Panahi, Ibid.

${ }^{31}$ Carlsson and Lundrstrom, Ibid.

${ }^{32}$ Cebula, Ibid.

${ }^{33}$ Nelson and Singh, Ibid.
} 


\subsection{Bă̆ımlı ve Bağımsız Değişkenlere Ait Veriler}

Çalışmanın bağımlı değişkeni savunma harcamaları, bağımsız değişkenleri Fraser Enstitüsü'nün genel ekonomik özgürlükler endeksi ve endeksin 5 ana bileşeninden oluşmaktadır. Bu değişkenlere ek olarak nüfusun büyüme hızı, enflasyon oranı ve GSYH büyüme oranı çalışmaya kontrol değişkeni olarak dâhil edilmiştir.

Dunne (1996) savunma harcamalarına ait verileri değerlendirirken özellikle gelişmekte olan ülkelerde verilerin tanımı, kapsamı ve doğruluğu ile ilgili sorunlar yaşanabileceğini belirterek bu tür durumların kesit analizleri için önemli olduğu fakat zaman serileri için çok fazla önemli olmadığını, alternatif veriler olsa da araştırmacıların çoğunun askerî harcamaların GSYH ya da GSMH oranını kullandığını ifade etmiştir. ${ }^{34}$

Çalışmada, analizin yapılmasında ve verilerin yorumlanmasında kolaylık sağlayacağı düşüncesiyle SIPRI'den derlenen savunma harcamalarının GSYH içerisindeki yüzdelik payı kullanılmıştır.

Ekonomik özgürlüklerin ekonominin diğer parametreleriyle sayısal olarak karşılaştırılıp analiz edilebilmesi için, çeşitli kurumlar bazı bileşenler belirleyerek ülkeler bazında endeksler yayınlamaya başlamıştır. Fraser Enstitüsü, Heritage Vakfı ve Freedom House gibi kurumlar her yıl belirledikleri kriterlere göre ülkeleri ekonomik özgürlüklerine göre sıralayarak aynı zamanda ülkeler arasında karşılaştırma yapma imkânı da sağlamaktadır.

Literatürde her üç kuruluşun endeksini kullanan çalışmalar mevcuttur. Çalışmada Fraser Enstitüsü'nün endeksi puanlama türünün sayısal ölçümlere dayanması, puanlama biçimi, ana ve alt endekslerin verilerine ulaşılma kolaylığı gibi nedenlerle Fraser Enstitüsünün ekonomik özgürlük endeksine ait veriler kullanılmıştır.

Fraser Enstitüsü, 1970 yılından itibaren ekonomik özgürlük endeksi yayınlayan Kanada merkezli bir politika enstitüsüdür. Endeks 5 ana bileşen

34 Paul Dunne, J., "Economic Effects of Military Expenditure in Developing Countries", Gleditsch, N.P., Bjerkholt, O., Cappelen, A., Smith, R. and Dunne, J.P. (Ed.) The Peace Dividend (Contributions to Economic Analysis, Vol. 235), Emerald Group Publishing Limited, Bingley, 1996, pp. 439-464. 
ve 24 alt bileşenden toplamda 42 farklı değişkenden oluşmaktadır. Her ana bileşen ve alt bileşen, altında yer alan değişkenlere ait verilen dağılımı yansıtan 0-10 arasındaki bir ölçeğe yerleştirilir ve her alan içindeki bileşenlerin değerlendirilmesi, beş alanın her biri için derecelendirme elde etmek amaciyla ortalanır. Ortalama sonucunda en yüksek sayısal değere sahip ülkeden başlayarak sıralama yapılır. Endeksin 5 ana bileşeni: Devletin Faaliyet Alanının Genişliği, Hukuki Yapı ve Mülkiyet Hakları, Güçlü Paraya Erişim, Uluslararası Ticaret Serbestisi, Kredi, İşgücü ve İş Dünyası Konusunda Yasal Düzenlemeler şeklindedir. ${ }^{35}$

Enstitü 1970-2000 yılları arasında endeksi beşer yıllık periyodlar halinde, 2000 yılından sonra ise yıllık olarak açıklamıştır. 2016 yılındaki raporunu 159 ülke için 2014 yılına ait en güncel verileri kullanılarak yayınlamıştır. ${ }^{36} \mathrm{Bu}$ nedenle çalışmada $2000-2014$ yılları inceleme periyodu olarak seçilmiş, analize dâhil edilen ve edilemeyen ülkeler nedenleri ile birlikte Tablo 2'de verilmiştir.

Tablo 2: Fraser Enstitüsü Ekonomik Özgürlük Endeksi İçerisinde Yer Alan ve Analize Dâhil Edilen/Edilmeyen Ülkeler

\begin{tabular}{|c|c|c|c|c|c|c|}
\hline Almanya & $\begin{array}{c}\text { Burkina } \\
\text { Faso }^{\star}\end{array}$ & Gabon & İzlanda ${ }^{\star \star}$ & Lüksemburg & Pakistan & Tacikistan ${ }^{\star}$ \\
\hline $\begin{array}{c}\text { Amerika } \\
\text { Birleşik } \\
\text { Devletleri }\end{array}$ & Burt & Gam & a & $\mathrm{Ma}$ & Par & ya \\
\hline Angola $\star \star \star \star$ & Butan $^{\star}$ & Gang & Ian & skar & $\begin{array}{c}\text { Papua Yeni } \\
\text { Gine }\end{array}$ & Tayland \\
\hline Arjantin & Cape Verde ${ }^{\star}$ & Ginet & Kamboçya $^{\star \star}$ & Make & Paraguay & Tayvan \\
\hline Arnavutluk & Cezayir & Gine-Bissau & Kamerun & Malawi & Peru & $\begin{array}{l}\text { Timor- } \\
\text { Leste }^{\star}\end{array}$ \\
\hline Avus & Ç. & Guatemala & $V$ & 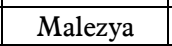 & $\mathrm{Pol}$ & Togo \\
\hline Avusturya & \begin{tabular}{|c|} 
Çek \\
Cumhuriyeti
\end{tabular} & Guyana & Karadağ ${ }^{\star}$ & Mali & Portekiz & $\begin{array}{c}\text { Trinidad ve } \\
\text { Tobago }\end{array}$ \\
\hline Azerbaycan ${ }^{\star}$ & Çin & Güney Afrika & Tatar* & 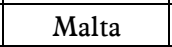 & Ro & Tunus \\
\hline Bahamalar $\star \star$ & Danimarka & Güney Kore & Kazakistan $^{\star}$ & Meksika & Ruanda & Türkiye \\
\hline Bahreyn & \begin{tabular}{|l|} 
Dem. Kongo \\
Cumhuriyeti
\end{tabular} & Gürcistan ${ }^{\star}$ & Kenya & Misir & Rusya & Uganda \\
\hline
\end{tabular}

${ }^{35}$ Fraser Institute, https://www.fraserinstitute.org/ (Erişim Tarihi: 18 Şubat 2017).

${ }^{36}$ James. D. Gwartney, Robert Lawson et al. "Economic Freedom of the World 2016" Annual Report, The Fraser Institute. Canada, 2016. 
Savunma Harcamaları ve Ekonomik Özgürlükler İlişkisi

\begin{tabular}{|c|c|c|c|c|c|c|}
\hline Bangladeş & \begin{tabular}{|c|} 
Dominik \\
Cumhuriyeti \\
\end{tabular} & Haiti $^{\star \star}$ & Kibris & Moğolistan $\star$ & Senegal & Ukrayna \\
\hline Barbados $^{\star \star}$ & Ekvador & Hirvatistan & $\begin{array}{c}\text { Kırgiz } \\
\text { Cumhuriyeti^}\end{array}$ & Moldova $^{\star}$ & $\begin{array}{c}\text { Seyşel } \\
\text { Adalar1 }^{\star}\end{array}$ & Umman \\
\hline Belçika & El Salvador & Hindistan & Kolombiya & Moritanya ${ }^{\star}$ & Surbistan $\star \star$ & Uruguay \\
\hline Belize & Endonezya & Hollanda & \begin{tabular}{|c|} 
Kongo \\
Cumhuriyeti \\
\end{tabular} & Morityus & Sierra Leone & Ürdün \\
\hline $\operatorname{Benin}^{\star \star}$ & Ermenistan $^{\star}$ & Honduras & Kosta Rika $a^{\star \star}$ & Mozambik $^{\star}$ & Singapur & Venezuela \\
\hline \begin{tabular}{|c|} 
Birleşik Arap \\
Emirliği \\
\end{tabular} & Estonya & 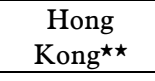 & Kuveyt & Myanmar ${ }^{\star}$ & \begin{tabular}{|c|} 
Slovak \\
Cumhuriyeti
\end{tabular} & Vietnam $^{\star}$ \\
\hline $\begin{array}{c}\text { Birleşik } \\
\text { Krallık } \\
\end{array}$ & Etiyopya $^{\star}$ & İran & Laos $\star$ & Namibya & \begin{tabular}{|l|} 
Slovenya \\
\end{tabular} & $\begin{array}{c}\text { Yemen } \\
\text { Cumhuriyeti }^{\star}\end{array}$ \\
\hline Bolivya & Fas & İrlanda & Lesotho ${ }^{\star}$ & Nepal & Sri Lanka & Yeni Zelanda \\
\hline $\begin{array}{c}\text { Bosna } \\
\text { Hersek }^{\star \star \star \star}\end{array}$ & Fiji & İspanya & Letonya & Nijer & Surinam ${ }^{\star}$ & Yunanistan \\
\hline Botsvana & $\begin{array}{c}\text { Fildişi } \\
\text { Sahilleri } \\
\end{array}$ & İsrail & Liberya $^{\star}$ & Nijerya & Suriye ${ }^{\star \star \star \star}$ & Zambiya \\
\hline Brezilya & Filipinler & İsveç & Libya $^{\star}$ & Nikaragua & $\begin{array}{c}\text { Suudi } \\
\text { Arabistan }\end{array}$ & Zimbabve ${ }^{\star}$ \\
\hline \begin{tabular}{|c|} 
Brunei \\
Darussalam \\
\end{tabular} & Finlandiya & İsviçre & Litvanya & Norveç & Svaziland ${ }^{\star}$ & \\
\hline Bulgaristan & Fransa & İtalya & Lübnan ${ }^{\star}$ & $\begin{array}{c}\text { Orta Afrika } \\
\text { Cumhuriyeti }{ }^{\star \star}\end{array}$ & Şili & \\
\hline
\end{tabular}

Kaynak: Fraser Enstitüsü.

^ Ekonomik Özgürlük Endeksinde verisi bulunmaması sebebiyle analize katılmayan ülkeler,

$\star \star$ Bağımlı ya da kontrol değişken verilerinin bulunamaması sebebiyle analize katılmayan ülkeler.

Modern toplum öncesinde savaş ve çatışmalara katılmak ülkenin refahını arttırmak için bir yol olarak görülürken, günümüz dünyasında ülkeler çatışma ve savaşı mümkün olduğu kadar kaçınılması gereken bir durum olarak ilişkilendirmişlerdir. Literatürde savaştan kaçınılması ve barışın arttırılmasında iki ana faktör önerilmektedir. Bunlardan ilki serbest ticaret, diğeri ise demokrasi ve temsili hükümetin barışı arttıracağı görüşüdür. ${ }^{37}$

Savunma harcamalarına ayrılan kaynaklar, bir ülkenin mevcut güvenliğinin sağlanması ya da çatışma ortamında bulunması gibi nedenlerin derecelerine göre farklılık gösterebilir. Ekonomik özgürlükler, içeriğinde

${ }^{37}$ Cara Burgess, Scott Beaulier et al." Economic Freedom and Conflict: An Empirical Note", Fournal of Economics and Economic Education Research, 2009 10(3), p. 75-83. 
yer alan konuların çatışmayı engelleyebilecek unsurlar sunması sebebiyle, savunmaya ayrılan kaynaklarda azalış meydana getirebilir. Bu nedenle hem genel ekonomik özgürlükler endeksi hem de içeriğindeki ana başl1klara ait endeksler incelenmelidir.

Çalışmada, ekonomik özgürlükleri geliştirerek çatışmadan kaçmanın savunma harcamaları üzerinde azaltıcı etkisi olabileceği düşüncesiyle oluşturulan hipotez:

Hipotez I: Ekonomik özgürlüklerde meydana gelen artıslar savunma harcamalar üzerinde azalışlara neden olabilir biçimindedir.

Fraser Enstitüsü'nün ilk ana başlığı olan Devletin Faaliyet Alanının Genişliği, ekonomideki kamu sektörünün büyüklüğünü ifade etmektedir. Temel olarak ifade edilmek istenen, devletin ekonominin içerisindeki yeri ne kadar büyürse özgürlüklerin o kadar azalacağıdır. Tablo 3, Devletin Faaliyet Alanının Genişliğine ait alt bileşenleri göstermektedir.

\section{Tablo 3: Devletin Faaliyet Alanının Genişliği Alt Bileşenleri}

\section{Devletin Faaliyet Alanının Genişliği: Harcamalar, Vergiler ve Girişimler}

A. Kamu tüketimi

B. Transferler ve sübvansiyonlar

C. Kamu istirakleri ve yattrmlar

D. En yüksek vergi oranı

i) En yüksek nihai gelir vergisi oranı

ii) En yüksek nihai gelir ve ücret vergisi oranı

Kaynak: Fraser Enstitüsü.

Kamu tüketimi ve transferler ve sübvansiyonlar alt başlıklarında, hükümet harcamalarının; bireylerin, hane halklarının ve işletmelerin harcamalarına oranla artması durumunda politik seçimlerin bireysel seçimlerin önüne geçtiği ve bu durumun ekonomik özgürlükleri kısıtladığı ifade edilmektedir. Bir başka ifadeyle kamu harcamalarının toplam içerisindeki payının artması endeks için olumsuz bir durumu yansıtmaktadır. ${ }^{38}$

\footnotetext{
${ }^{38}$ Gwartney and Lawson, Ibid.
} 
Vergilendirme bileşenin, düşük vergi düzeylerinde uygulanan marjinal vergi oranlarının devlete bağlı bir yapıyı gösterdiğini, bu gibi oranların bireylerin emeklerinin karşılığını dışladığını dolayısıyla endeks içerisinde düşük puanlamaya neden olduğu ifade edilmiştir.

Devlet gelirlerinin büyük bir kısmını oluşturan vergilerdeki değişimler, kamu gelirlerinin hangi harcama kalemlerine ne oranda dağılacağını da etkilemektedir. Savunma harcamalarının da bir kamu harcama kalemi olduğu düşünüldüğünde bu harcamaların ihtiyacın büyüklüğüne göre değişebilse de gelire oranla da değişebilmesi muhtemeldir. Dolayısıyla vergi artışlarının gelir artışları anlamına geldiği ve bu gelir artışlarının savunma harcamalarında da artış meydana getirebileceği çıkarımı yapılmaktadır. Vergi artışlarının endeks için olumsuz bir durumu ifade etmesi nedeniyle devletin faaliyet alanı genişliğinde meydana gelen artısların savunma harcamalarını azaltacağ düşünülmektedir. Bu görüşle oluşturulan hipotez:

Hipotez II: Devletin faaliyet alanı genişliğinde meydana gelen artıslar savunma harcamalar üzerinde azalışlara neden olabilir biçimindedir.

Mülkiyet hakkı ve bireylerin korunması ekonomik özgürlüğün ve sivil toplumun temelini oluşturmaktadır. Devletin temel görevlerinden olan koruyuculuk fonksiyonunun ne kadar işlevsel olduğunu ölçmek için 9 alt bileşen oluşturulmuştur. Bu başlı̆̆ın endeks içerisinde yer alan ana başlıkların en önemlisi olduğu ifade edilmektedir. Mülkiyet haklarının güvence altında olduğu ülkeler ekonomik özgürlük endeksinde daha yüksek değer alırlar. Tablo 4, Hukuki Yapı ve Mülkiyet Hakları Alt Bileşenlerini oluşturan 9 bileşeni göstermektedir.

\section{Tablo 4: Hukuki Yapı ve Mülkiyet Hakları Alt Bileşenleri}

\section{Hukuki Yapi ve Mülkiyet Hakları}
A. Yargı bă̆ımsızlı̆̆ı
B. Tarafsı mahkemeler
C. Mülkiyet haklarinin korunması
D. Yasalar ve politik sisteme askerî müdahale
E. Yasal düzenin bütünlüğü
F. Sözleşmelerin yasal bağlayıcılı̆̆
G. Fiziki değerlerin satışıın kısıtlanmasına ilişkin düzenlemeler
H. Polise güven
I. Suçun maliyeti

Kaynak: Fraser Enstitüsü. 
Hukukun üstünlüğü ve mülkiyet haklarının güvenliği piyasaların etkin çalışması için önemli olduğu kadar ekonomik özgürlükler için de çok önemlidir. Bireyler ve işletmeler sözleşmelerin korunmayacağını ve çabalarının sonuçlarını güvensizlik nedeniyle alamayacağını düşünürse ekonomik faaliyete katılmayabilirler. ${ }^{39}$

Devletin en önemli işlevleri arasında sayılabilecek vatandaşları ve malları koruma işlevi; ulusal savunma, polis koruması ve adalet sistemiyle sağlanmaktadır. Endekste bu durumun güçlü bir adalet sistemiyle sağlanacağına işaret edilmektedir. Adalet sisteminin güçsüzleşmesi piyasa sistemini de zayıflatmaktadır. ${ }^{40}$ Piyasa sisteminde meydana gelen zayıflamalar da zamanla toplumda çatışma doğurabilir.

Adalet sisteminin işlerliğinin yüksek olması suçu caydırıcı etki yapabilir. Bunun yanında yasalara ve politik sisteme yapılacak askerî müdahalelerin azlığı da endeks içerisinde yüksek bir değer ifade etmektedir. Adalet sisteminin yüksek düzeyde işler olmasının suçu caydırıcı etkisi olabileceği düşünüldüğünde bu durum iç savunmaya harcanan kaynaklarda azalış meydana getirebilir. Bu görüşle oluşturulan hipotez:

Hipotez III. Hukuki Yapı ve Mülkiyet Haklarnda meydana gelen artışlar savunma harcamalar üzerinde azalıslara neden olabilir biçimindedir.

Güçlü parayla ifade edilen, bireylerin istikrarlı ve güçlü paraya ulaşabilmesidir. Yüksek parasal büyümenin enflasyona yol açması, bunun da işletmelerin planlamalarını sekteye uğratması endeks için olumsuz durumdur. Tablo 5, Güçlü Paraya Erişim ana bileşeninin alt bileşenlerini göstermektedir.

\section{Tablo 5: Güçlü Paraya Erişim Alt Bileşenleri}

\section{Güçlü Paraya Erişim \\ A. Para büyüklüğ̈̈ \\ B. Enflasyonun standart sapmast \\ C. Enflasyon: En güncel yrl \\ D. Yabancı para cinsinden banka hesabı açma özgürlü̆̈̈̈}

Kaynak: Fraser Enstitüsü.

\footnotetext{
${ }^{39}$ Ibid.

${ }^{40}$ James Gwartney and Robert Lawson, "The Concept and Measurement of Economic Freedom”, European Fournal of Political Economy, 2003, 19.3, 405-430.
} 
Yüksek enflasyon, parasal istikrarsızlık ve beklenmedik fiyat değişimleri refah dağılımının bozulmasına ve değişmesine neden olabilir. $\mathrm{Bu}$ gibi durumlar da bireylerin sahip oldukları servetlerin erimesine neden olur. Dolayısıyla bireylerin servetlerini koruyabilme özgürlüğ̈ kısıtlanır. ${ }^{41}$ Hükümetler harcamalarını para basarak finanse ettikleri zaman mülkleri kamulaştırmakta ve bireylerin ekonomik özgürlüklerini ihlal etmektedirler. ${ }^{42}$

Güçlü para içerisinde yer alan enflasyon alt başlığı, savunma harcamalarının güçlü para ile olan ilişkisini enflasyon üzerinden değerlendirme imkânı sunabilir. Literatürde (Melman, ${ }^{43}$ 1970; Hamilton, ${ }^{44}$ 1977; Stein ${ }^{45}$ 1980) savunma harcamaları ile ilgili yapılan çalışmalarda savunma harcamalarının enflasyona neden olduğu yönünde birçok sonuç mevcuttur. Bir diğer görüş ise (Kaufman, ${ }^{46}$ 1972; Capra, ${ }^{47}$ 1981) enflasyonun savunma harcamalarına etkisi olduğu yönündedir.

Enflasyon artışlarının maliyetler üzerindeki etkisiyle satın alma gücündeki azalmalar, savunma harcamaları satın almaları üzerinde de kendini gösterebilir. Bir başka durumda bir devlet başka bir devletin enflasyon nedeniyle artan savunma harcamalarına uyum sağlamak için kendi savunma harcamalarını da arttırabilir. Bu bağlamda enflasyonun savunma harcamalarına etki eden önemli bir belirleyici olduğu göz önünde bulundurulmalıdır. ${ }^{48}$

Savunma harcamaları yönünden baktığımızda savunma harcamalarında meydana gelecek artışlar para basarak ya da vergilerin artmasıyla finanse edilirse bu durum enflasyon artışına yol açabilir. Enflasyonun satın alma

${ }^{41}$ Ahmet Beşkaya ve Asuman Koç, "Ekonomik Büyüme ve Kalkınmada Ekonomik Özgürlüklerin Rolü ve Önemi”, Liberal Düşünce, 2006, 43, ss. 43-74.

${ }^{42}$ Gwartney and Lawson, Ibid.

${ }^{43}$ Seymour Melman, "The Defense Economy: Conversion of Industries and Occupations to Civilian Needs", Praeger Publishers, 1970, New York.

${ }^{44}$ Earl. J. Hamilton, "The Role of War in Modern Inflation." Fournal of Economy History, 1977, 37(1), p. 13-19.

${ }^{45}$ Arthur. A. Stein, The Nation at War, Baltimore, MD: Johns Hopkins Univ. Press, 1980.

${ }^{46}$ R. F. Kaufman, "The Pentagon Stokes Inflation”, The Nation, 1972, (May 1), p. 555-558.

${ }^{47}$ James. R. Capra, "The National Defense Budget and its Economic Effects", Federal Reserve Bank of New York Q. Rev, 1981, 6, p. 21-31.

${ }^{48}$ Tayfun Günana, The Relationship Between Defense Spending and Inflation: An Emprical Analysis for Turkey, Master of Business Administration Thesis, The Institute of Economics and Social Sciences of Bilkent University, Ankara. 2004. 
etkisi üzerinde yarattığı azalmalar, hedeflenen savunma harcamalarında bir azalış meydana getirmediği zaman, savunma harcamalarına ayrılan kaynağın artması anlamını taşımaktadır. Bu açıdan bakıldığında bağımsız değişken olan güçlü para ile savunma harcamaları arasında ilişki kurulabilir. Enflasyon artışlarının endekste daha az puanlamaya karşılık geldiği düşünülürse bu görüşle oluşturulan hipotez:

Hipotez IV: Güçlü Paraya Erişimde meydana gelen artıslar savunma harcamalar üzerinde azalıslara neden olabilir biçimindedir.

Günümüz dünyasında ulusların birbirleri arasındaki ticareti ekonomik özgürlüklerin anahtarlarından biridir. Birçok mal ve hizmetin yurtdışında üretildiği ya da yurtdışından sağlanan kaynaklarla üretildiği düşünüldüğünde ticaret serbestisinin ticareti gerçekleştiren her iki taraf için de önemli olduğu açıktır. ${ }^{49}$ Tablo 6, Uluslararası Ticaret Serbestisi'nin alt bileşenlerini göstermektedir.

Tablo 6: Uluslararası Ticaret Serbestisi Alt Bileşenleri

\section{Uluslararası Ticaret Serbestisi}

A. Tarifeler

i) Ticari vergi geliri

ii) Ortalama tarife oranı

iii) Tarife oranlarmin standart sapmast

B. Ticari engeller

i) Tarife disı ticari engeller

ii) Ithalat ve ihracata uyum maliyetleri

C. Karaborsa değişim oranlar

D. Insanların ve sermayenin dolaşımının kontrolü

i) Yabancı mülkiyet/yatırım kısıtlamalar

ii) Sermaye kontrolleri

iii) Yabancı ziyaretçi özgürlüğü

Kaynak: Fraser Enstitüsü.

Tarifeler ve kontenjanlar, uluslararası ticareti sinırlayan barikatların en bilinen örnekleridirler. Döviz kurundaki kontroller paranın konvertibl olmasını azaltması nedeniyle uluslararası ticareti de engellemektedir.

\footnotetext{
${ }^{49}$ Gwartney and Lawson, Ibid.
} 
Endeks içerisinde düşük tarifeli, etkin ve kolay geçişli gümrük idaresi, para konvertiblinin serbestisi ve insanların ve sermayenin üzerindeki kontrollerin az olması yüksek olarak puanlanmaktadır. ${ }^{50}$

Savunma harcamalarının uluslararası ticaret serbestisi ile olan ilişkisi, daha önce de ifade edilen savaştan kaçınılması ve barışın arttırılmasındaki iki ana faktörden biri olan serbest ticaretle ilişkilidir.

Fransız ekonomist Frederic Bastiat sınırları malların geçmemesi halinde ordunun geçeceğini ifade ederken; Kant (1795), sürekli barış1 sağlamanın yollarından birinin ekonomik bağımlılık olduğunu ileri sürmüştür. ${ }^{51}$ Yakın zamanlardaki klasik liberallerin ekonomik bağımlılık hipotezi ise ticaret-barış hipotezine evrilmiştir. ${ }^{52}$

Endekste uluslararası ticaretin serbestleştirilmesinin daha yüksek puanlamaya neden olacağı, ticareti geliştirmenin barışı getirebileceği, barışın da savunma harcamaları üzerinde azalışa neden olacağı düşüncesiyle oluşturulan hipotez:

Hipotez V: Uluslararası Ticaret Serbestisinde meydana gelen artıslar savunma harcamalar üzerinde azalıslara neden olabilir biçimindedir.

Yasal düzenlemeler, piyasaya girişleri kısıtladığı ve takas özgürlügüne müdahale ettiği zaman özgürlükleri kısıtlayıcı etkiye sahiptir. Endeks içerisinde düzenlemeler, geniş bir yelpazede ele alınmıştır. Tablo 7, Kredi, İşgücü ve İş Dünyası Konusunda Yasal Düzenlemelere ilişkin alt bileşenleri göstermektedir.

\footnotetext{
${ }^{50}$ Ibid.

${ }^{51}$ Kant, Ibid.

${ }^{52}$ Burges and Beaulier et al, Ibid, p. 76.
} 


\section{Tablo 7: Kredi, İşgücü ve İş Dünyası Konusunda Yasal Düzenlemelere İlişkin Alt Bileşenler}

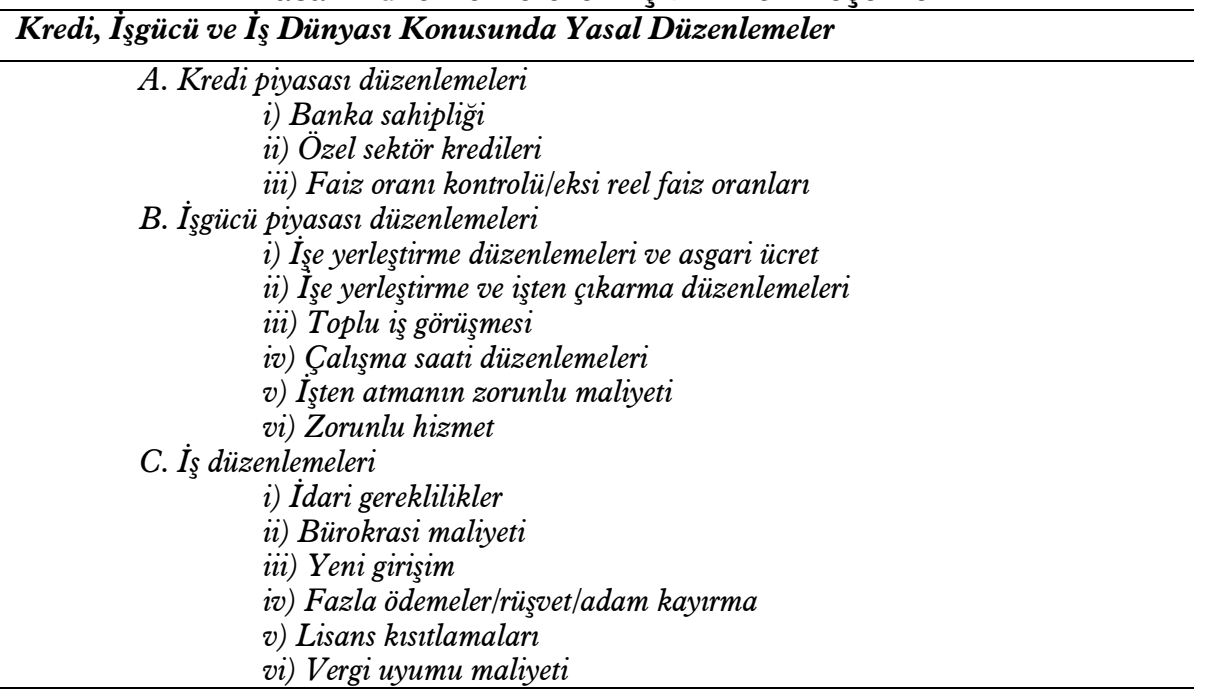

Kaynak: Fraser Enstitüsü.

İşletmelerde ekonomik açıdan yasal düzenlemelere gidilmesi ekonomik büyüme açısından gereklidir. Yasal asgari ücretler, işten çıkarılmaya ilişkin düzenlemeler ve işten atmanın zorunlu maliyeti gibi bireylerin güvenli çalışmasına olanak sağlayacak düzenlemeler ise zamanla iş gücünün çalışma güdüsünde azalma meydana getirebilir. Bunun yanı sıra sendikalaşma, maliyetler üzerinde artışa sebep olabileceğinden ekonomik büyüme üzerinde olumsuzluklara yol açabilir. ${ }^{53}$

Yasal düzenlemelerin ekonomik büyüme üzerinde oluşturabileceği negatif etki göz önünde bulundurulsa da yapılan iyileştirmelerin endeksin diğer kalemlerine, özellikle ticaret serbestisine olumlu yansıyacağı düşünülmektedir. Geliştirilen yasal düzenlemelerle birlikte piyasaya girişler kolaylaşacak, ülkelerle gelişen ticaretle birlikte savunma harcamalarında azalışlar meydana gelebilecektir. Bu temelde oluşturulan hipotez:

\footnotetext{
${ }^{53}$ Beşkaya ve Koç, a.g.e, s. 11.
} 
Hipotez VI: Yasal Düzenlemelerde meydana gelen artıslar savunma harcamalar üzerinde azalıslara neden olabilir biçimindedir.

Gelir ile savunma harcamaları arasındaki ilişkiyi inceleyen çalışmalarda, ülkelerin kendilerine özgü dinamikleri de söz konusu ilişkinin varlığı ve yönü hususunda son derece etkilidir. Ülkeler arasındaki ekonomik gelişmişliklerin farklılıkları dikkate alındığında, GSYH büyüme oranı analize yardım edecek bir kontrol değişkeni olarak incelemeye dâhil edilmiştir.

GSYH büyüme oranı verileri, 2000-2014 y1lları arasında analize dâhil edilen 110 ülke için 2010 yılı ABD doları baz alınarak hesaplanan Dünya Bankası verilerinden derlenmiştir.

Nüfusun büyüme hızı, ülkeler arasındaki farklı yoğunluktaki nüfus değişimlerini göz önünde bulundurmak için analize yardım edecek bir kontrol değisskeni olarak incelemeye dâhil edilmiştir.

Nüfusun büyüme hızı verileri, 2000-2014 yılları arasında analize dâhil edilen 110 ülke için yıllık değişim olarak Dünya Bankası, Birleşmiş Milletler, CIA World Factbook verilerinden derlenmiştir.

Ülkeler arasındaki enflasyon oranlarının yaratabileceği farklılıklar dikkate alındığında enflasyon oranı analize yardım edecek bir kontrol değişkeni olarak incelemeye dâhil edilmiştir. Enflasyon verileri, 20002014 yılları arasında analize dâhil edilen 110 ülke için yıllık değişim olarak tüketici fiyatları üzerinden Dünya Bankası ve Uluslararası Para Fonu verilerinden derlenmiştir.

Tablo 8, yukarıda ifade edilen bağıml, bağımsız ve kontrol değişkenlerine ait hipotezleri, analiz sonunda gerçekleşmesi beklenen ilişkinin yönünü, verilerin kodlarını ve kaynaklarına ait özet bilgileri içermektedir. 
Tablo 8: Değişkenlere Ait Özet Bilgiler

\begin{tabular}{|c|c|c|c|c|c|}
\hline Değişken & $\begin{array}{l}\text { Analiz } \\
\text { Kodu }\end{array}$ & Kaynak & Veri Türü & Hipotez & $\begin{array}{l}\text { Beklenen } \\
\text { İşaret }\end{array}$ \\
\hline Savunma Harcamaları & LSH & SIPRI & $\begin{array}{c}\% \\
(\mathrm{GSYH}) \\
\end{array}$ & & \\
\hline $\begin{array}{l}\text { Genel Ekonomik } \\
\text { Özgürlük Endeksi }\end{array}$ & LEO & $\begin{array}{l}\text { Fraser Enstitüsü } \\
\text { Ekonomik } \\
\text { Özgürlük Endeksi }\end{array}$ & $\begin{array}{l}\text { Endeks } \\
\text { Puanı }\end{array}$ & I & - \\
\hline $\begin{array}{l}\text { Devletin Faaliyet } \\
\text { Alanının Genişliği: } \\
\text { Harcamalar, Vergiler } \\
\text { ve Girişimler }\end{array}$ & LDG & $\begin{array}{l}\text { Fraser Enstitüsü } \\
\text { Ekonomik } \\
\text { Özgürlük Endeksi }\end{array}$ & $\begin{array}{l}\text { Endeks } \\
\text { Puanı }\end{array}$ & II & - \\
\hline $\begin{array}{l}\text { Hukuki Yapı ve } \\
\text { Mülkiyet Hakları }\end{array}$ & LMH & $\begin{array}{l}\text { Fraser Enstitüsü } \\
\text { Ekonomik } \\
\text { Özgürlük Endeksi }\end{array}$ & $\begin{array}{l}\text { Endeks } \\
\text { Puanı }\end{array}$ & III & - \\
\hline Güçlü Paraya Erişim & LGP & $\begin{array}{l}\text { Fraser Enstitüsü } \\
\text { Ekonomik } \\
\text { Özgürlük Endeksi }\end{array}$ & $\begin{array}{l}\text { Endeks } \\
\text { Puanı }\end{array}$ & IV & - \\
\hline $\begin{array}{c}\text { Uluslararası Ticaret } \\
\text { Serbestisi }\end{array}$ & LUT & $\begin{array}{l}\text { Fraser Enstitüsü } \\
\text { Ekonomik } \\
\text { Özgürlük Endeksi }\end{array}$ & $\begin{array}{l}\text { Endeks } \\
\text { Puanı }\end{array}$ & V & - \\
\hline $\begin{array}{l}\text { Kredi, İşgücü ve İş } \\
\text { Dünyası Konusunda } \\
\text { Yasal Düzenlemeler }\end{array}$ & LYD & $\begin{array}{l}\text { Fraser Enstitüsü } \\
\text { Ekonomik } \\
\text { Özgürlük Endeksi }\end{array}$ & $\begin{array}{l}\text { Endeks } \\
\text { Puanı }\end{array}$ & VI & - \\
\hline GSYH Büyüme Oranı & LGBO & Dünya Bankası & $\begin{array}{c}\% \\
\text { (Yüzde) }\end{array}$ & &,-+ \\
\hline Nüfusun Büyüme Hızı & $\mathrm{LNBH}$ & $\begin{array}{c}\text { Dünya Bankası, } \\
\text { Birleşmiş } \\
\text { Milletler, CIA } \\
\text { World Factbook }\end{array}$ & $\begin{array}{c}\% \\
\text { (Yüzde) }\end{array}$ & &,-+ \\
\hline Enflasyon Oranı & LENF & $\begin{array}{c}\text { Dünya Bankası ve } \\
\text { Uluslararası Para } \\
\text { Fonu }\end{array}$ & $\begin{array}{c}\% \\
\text { (Yüzde) }\end{array}$ & & + \\
\hline
\end{tabular}

Kaynak: Yazar tarafından derlenmiştir.

“-”: Negatif yönlü ilişki, “+”: Pozitif yönlü ilişki”.

\subsection{Panel Veri Analizi ve Birim Kök Testleri}

Panel veri, zaman boyutuna sahip yatay kesit serilerini kullanarak verilerin hem zaman boyutunu hem de yatay kesit boyutunu bir araya getirme imkânı sunan ve en az iki boyut içeren verilerdir. Daha az çoklu 
doğrusallık içerdiği için tahminlerin verimliliğini arttırırken, daha karmaşık hipotezler kurmada, atlanan değişkenlerin etkisini kontrol etmede ve dinamik ilişkileri açığa çıkarmada kolaylık sağlamaktadır. ${ }^{54}$ Bunun yanı sıra verilerin ülke ve bölgeleri kapsaması durumunda seçicilik yaparak sapma problemleri oluşturabilmesi ve veri setinin geniş olması nedeniyle ölçüm hatalarının fazla olabilmesi dezavantajları arasında yer alır. ${ }^{55}$

Hem kesit boyutu hem de zaman boyutu içeren panel veriler için genel doğrusal model eşitlik (6)'da gösterildiği gibidir.

$$
Y_{i t}=\alpha_{i t}+X_{i t} \beta_{i t}+u_{i t}
$$

Eşitlikte yer alan $Y$ bağımlı değişkeni, $i$ birimi (kesit), $t$ zaman periyodunu, $\alpha$ sabit terimi, $\beta_{i t}$ eğim katsayısını, $X_{i t}$ i biriminin $\mathrm{t}$ zamanındaki açıklayıcı değişken değerini ve $u_{i t}$ hata terimini ifade etmektedir. $^{56}$

Panel veri setleri, zaman serileri ve yatay kesit verilerinin birleşiminden oluşması nedeniyle serilerin durağanlık sorunu ortaya çıkabilmektedir. Analizde kullanılan verilerin birim köke sahip olmaması sonuçların güvenirliklerini arttırmaktadır. Verilerin grafiklerine bakarak durağan olup olmadıklarını görebileceğimiz gibi, çeşitli birim kök testleri ile de serilerin durağan olup olmadıkları kontrol edilebilmektedir.

Çalışmada verilerin hem grafiksel görünümü hem de ADF Chi Square $^{57}$ (1984), Philips-Perron ${ }^{58}$ (1999) ve Im $^{59}$, vd. (2003) testleri kullanılacaktır. Bu testlere ait hipotezler Tablo 9'da verilmiştir.

\footnotetext{
${ }^{54}$ Cheng Hsiao, "Why Panel Data?”, The Singapore Economic Review, 2005, 50(2), .143154, p. 146-148.

${ }^{55}$ Cheng Hsiao, Analysis of Panel Data. Cambridge University Press, Second Edition, United Kingdom, 2003.

56 A. Colin Cameron and Pravin. K. Triverdi, Microeconometrics Methods and Applications, Cambridge University Press, New York, 2005, p. 698.

${ }^{57}$ Michael. W. Browne, "Asymptotically Distribution Free Methods for the Analysis of Covariance Structures”. British Fournal of Mathematical and Statistical Psychology, 1984, 37, p. 62-83.

${ }^{58}$ Peter CB Phillips and Pierre Perron, "Testing For a Unit Root in Time Series Regression." Biometrika, 1988, 75.2, p. 335-346.

59 Kyung. S. Im, M. Hashem PESARAN et al.," Testing for Unit Roots in Heterogeneous Panels", Fournal of Econometrics, 2003, 115(1), p. 53-74
} 
Tablo 9: Birim Kök Testleri Hipotez Tablosu

\begin{tabular}{|l|c|c|c|}
\hline \multicolumn{1}{|c|}{ Test } & $\begin{array}{c}\text { Im, Pesaran } \\
\text { and Shin W-stat }\end{array}$ & $\begin{array}{c}\text { ADF - Fisher } \\
\text { Chi-square }\end{array}$ & $\begin{array}{c}\text { PP - Fisher } \\
\text { Chi-square }\end{array}$ \\
\hline $\mathrm{H}_{0}: \alpha=0$ & $\begin{array}{c}\text { Birim Kök Var } \\
\text { (Seri Durağan Değil) }\end{array}$ & $\begin{array}{c}\text { Birim Kök Var } \\
\text { (Seri Durağan Değil) }\end{array}$ & $\begin{array}{c}\text { Birim Kök Var } \\
\text { (Seri Durağan Değil) }\end{array}$ \\
\hline $\mathrm{H}_{1}: \alpha<0$ & $\begin{array}{c}\text { Birim Kök Yok } \\
\text { (Seri Durağan) }\end{array}$ & $\begin{array}{c}\text { Birim Kök Yok } \\
\text { (Seri Durağan) }\end{array}$ & $\begin{array}{c}\text { Birim Kök Yok } \\
\text { (Seri Durağan) }\end{array}$ \\
\hline
\end{tabular}

Test sonucunda birim kök testlerine ait olas1lık değeri \%5 anlamlılık düzeyinden küçükse $H_{0}$ reddedilir ve serilerin durağan olduğu sonucuna ulaşılır. Olasılık değerleri \%5 anlamlılık düzeyinden büyükse birim kök vardır anlamını taşımaktadır.

Panel veri analizinde verilerin logaritmalarının alınması tahmin edilen değerlere ilişkin eş varyanslı (homoscedastic) regresyon hatalarının belirlenmesine yardımcı olmaktadır. ${ }^{60}$ Muhtemel bir değişen varyans (heteroscedasticity) sorununun önüne geçmesinin yanında serilerin daha kolay durağan hale gelmesi nedeniyle analizde kullanılan verilerin doğal logaritmaları alınacaktır.

\section{Ampirik Test ve Bulgular}

Analize geçmeden önce değişkenler arasında çoklu doğrusal bağlantının olup olmadığının saptanması için korelasyon matrisi oluşturulmuştur. Değişkenler arasındaki değerler "1" ya da “-1" den uzaklaştıkça çoklu doğrusal bağlantı olmadığı anlamını taşımaktadır. İki bağımsız değişken arasındaki basit korelasyon katsayısının anlamlılı̆̆ yüksekse $(r>0.75)$ değişkenler arasında çoklu doğrusal bağlantı olduğu düşünülür.

\footnotetext{
${ }^{60}$ Ridderstedt, Ibid.
} 
Tablo 10: Korelasyon Matrisi

LSH LEO LDG LMH LGP LUT LYD LGBO LNBH LENF

\begin{tabular}{ccccccccccccc}
\hline LSH & $\mathbf{1 . 0 0}$ & & & & & & & & & \\
LEO & -0.07 & $\mathbf{1 . 0 0}$ & & & & & & & & \\
LDG & -0.14 & 0.08 & $\mathbf{1 . 0 0}$ & & & & & & & \\
LMH & 0.08 & $\mathbf{0 . 7 7}$ & -0.32 & $\mathbf{1 . 0 0}$ & & & & & & \\
LGP & -0.09 & $\mathbf{0 . 8 0}$ & -0.10 & 0.55 & $\mathbf{1 . 0 0}$ & & & & & \\
LUT & -0.03 & $\mathbf{0 . 8 3}$ & -0.12 & 0.62 & 0.66 & $\mathbf{1 . 0 0}$ & & & & \\
LYD & -0.06 & 0.73 & -0.03 & 0.56 & 0.45 & 0.54 & $\mathbf{1 . 0 0}$ & & & \\
LGBO & 0.05 & -0.15 & 0.16 & -0.15 & -0.19 & -0.15 & -0.09 & $\mathbf{1 . 0 0}$ & & \\
LNBH & 0.10 & -0.29 & 0.27 & -0.33 & -0.32 & -0.33 & -0.15 & 0.20 & $\mathbf{1 . 0 0}$ & \\
LENF & -0.07 & -0.34 & 0.21 & -0.34 & -0.40 & -0.28 & -0.26 & 0.18 & 0.18 & $\mathbf{1 . 0 0}$ \\
\hline
\end{tabular}

Tablo 10'a göre genel ekonomik özgürlükler endeksi (LEO) ile Kredi, İşgücü ve İş Dünyası Konusunda Yasal Düzenlemeler (LYD), Uluslararası Ticaret Serbestisi (LUT), Hukuki Yapı ve Mülkiyet Hakları (LMH) ve Güçlü Paraya Erişim (LGP) arasında yüksek düzeyde çoklu doğrusal bağlantı görülmektedir. Ekonomik özgürlük endeksi ile ana bileşenleri arasında ortaya çıkan bu durum, değişkenler analize aynı anda dâhil edilmeyeceği için problem oluşturmamaktadır.

Tablo 11, değişkenlere ilişkin tanımlayıcı istatistikleri göstermektedir. Genel Ekonomik özgürlük endeksinin ortalaması ve medyanı minimuma daha yakın, endekse ilişkin ana başlıkların ortalama ve medyanları maksimuma daha yakındır. Buna göre analize dâhil edilen ülkelerin çoğu endeks içerisinde düşük puanlı fakat ana bileşenlerde yüksek puanlıdır.

Tablo 11: Tanımlayıcı İstatistikler

\begin{tabular}{ccccccc}
\hline Değişkenler & Gözlemler & Ortalama & Medyan & $\begin{array}{c}\text { Standart } \\
\text { Sapma }\end{array}$ & Minimum & Maksimum \\
\hline LSH & 1650 & 0.45 & 0.43 & 0.64 & -1.92 & 2.78 \\
LEO & 1650 & 1.91 & 1.94 & 0.13 & $\mathbf{1 . 1 9}$ & 2.18 \\
LDG & 1650 & 1.82 & 1.86 & 0.23 & 0.85 & 2.24 \\
LMH & 1650 & 1.68 & 1.74 & 0.33 & 0.14 & 2.26 \\
LGP & 1650 & 2.07 & 2.13 & 0.20 & 0.22 & 2.29 \\
LUT & 1650 & 1.96 & 1.99 & 0.17 & 0.94 & 2.25 \\
LYD & 1650 & 1.90 & 1.92 & 0.15 & 1.23 & 2.23 \\
LGBO & 1650 & 1.19 & 1.38 & 0.92 & -4.28 & 3.51 \\
LNBH & 1650 & 0.01 & 0.25 & 1.09 & -8.33 & 2.71 \\
LENF & 1650 & 1.22 & 1.28 & $\mathbf{1 . 1 4}$ & -7.39 & $\mathbf{6 . 2 4}$ \\
\hline
\end{tabular}


Mehmet Samet ERDEM - Selami SEZGIN

\section{Şekil 1: Verilere Ait Grafikler}

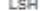
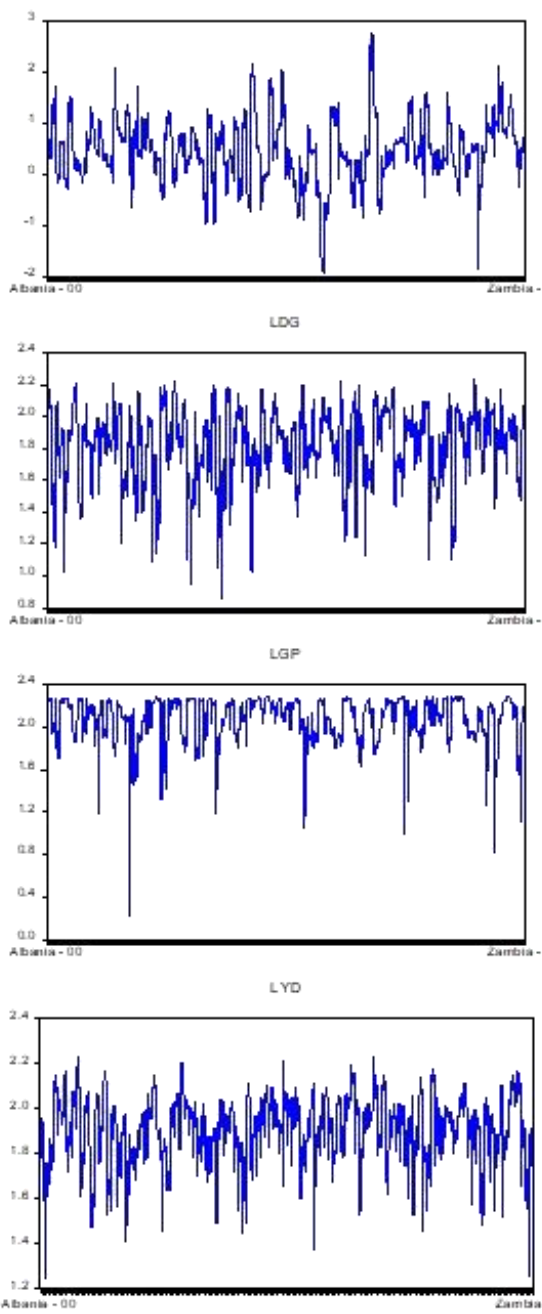

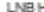

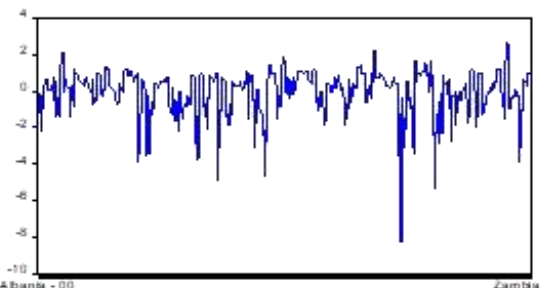

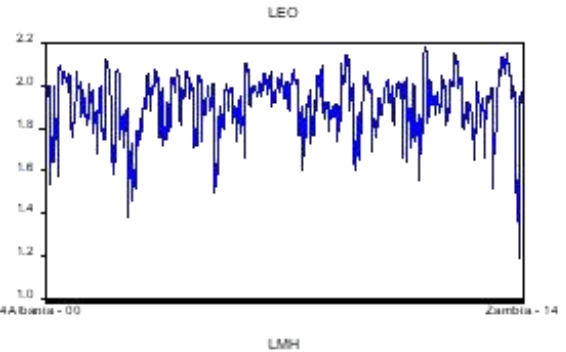
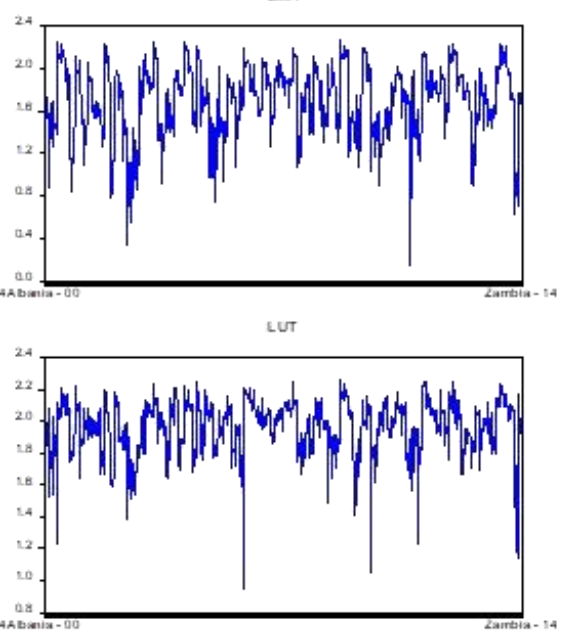

Baso

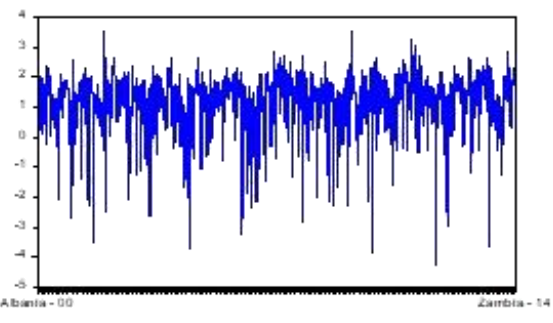

IENF

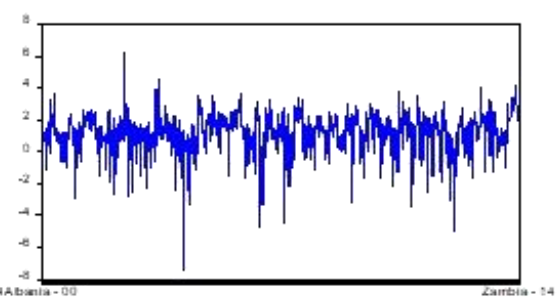


Şekil 1 verilere ait grafikleri, Tablo 12 ise değişkenlere ait birim kök testi sonuçlarını göstermektedir. Bütün verilerin birim kök testlerinin olasılık sonuçları 0.05 den küçük olduğu için Tablo 10'da yer alan hipotezlere göre reddedilerek kabul edilir. Dolayısıyla verilerin hepsinin durağan olduğu sonucuna ulaşılmıştır.

Tablo 12: Birim Kök Testi Sonuçları

\begin{tabular}{cccc}
\hline Değişkenler & $\begin{array}{c}\text { Im, Pesaran } \\
\text { and Shin W-stat }\end{array}$ & $\begin{array}{c}\text { ADF - Fisher } \\
\text { Chi-square }\end{array}$ & $\begin{array}{c}\text { PP - Fisher } \\
\text { Chi-square }\end{array}$ \\
\hline \multirow{2}{*}{ LSH } & -1.75280 & 261.166 & 260.810 \\
& $(0.0398)$ & $(0.0298)$ & $(0.0309)$ \\
LEO & -7.26223 & 410.683 & 395.891 \\
& $(0.0000)$ & $(0.0000)$ & $(0.0000)$ \\
LDG & -11.1495 & 509.565 & 468.694 \\
& $(0.0000)$ & $(0.0000)$ & $(0.0000)$ \\
LMH & -13.0823 & 579.546 & 573.302 \\
& $(0.0000)$ & $(0.0000)$ & $(0.0000)$ \\
LGP & -3.05396 & 280.299 & 546.930 \\
& $(0.0011)$ & $(0.0037)$ & $(0.0000)$ \\
LUT & -6.79244 & 368.929 & 419.520 \\
& $(0.0000)$ & $(0.0000)$ & $(0.0000)$ \\
LYD & -17.2307 & 738.419 & 474.159 \\
& $(0.0000)$ & $(0.0000)$ & $(0.0000)$ \\
LGBO & -8.25499 & 424.033 & 729.063 \\
& $(0.0000)$ & $(0.0000)$ & $(0.0000)$ \\
LNBH & -11.2819 & 600.516 & 369.879 \\
& $(0.0000)$ & $(0.0000)$ & $(0.0000)$ \\
LENF & -8.18045 & 428.416 & 593.306 \\
& $(0.0000)$ & $(0.0000)$ & $(0.0000)$ \\
\hline
\end{tabular}

Olasılık değerleri parantez içinde gösterilmiştir.

Tablo 13, her model için yapılan sabit ve rassal etkili sonuçları, rassal etki üzerinden hesaplanan Hausman testini, düzeltilmiş $R^{2}$ değerlerini, F istatistik sonuçlarını ve olasılıklarını göstermektedir. 
Mehmet Samet ERDEM - Selami SEZGIN

Tablo 13: Panel Veri Analizi Sonuçları

\begin{tabular}{|c|c|c|c|c|}
\hline Değişkenler & \multicolumn{2}{|c|}{ Model 1} & \multicolumn{2}{|c|}{ Model 2} \\
\hline & $S E$ & $\boldsymbol{R E}$ & $S E$ & $R E$ \\
\hline LEO & $\begin{array}{l}-1.13^{\star \star \star} \\
(0.10)\end{array}$ & $\begin{array}{c}-1.10^{\star \star \star \star} \\
(0.09)\end{array}$ & & \\
\hline LDG & & & $\begin{array}{c}-0.34^{\star \star \star \star} \\
(0.04)\end{array}$ & $\begin{array}{c}-0.35^{\star \star \star \star} \\
(0.04)\end{array}$ \\
\hline LMH & & & $\begin{array}{c}-0.27 \star \star \star \\
(0.04)\end{array}$ & $\begin{array}{c}-0.25^{\star \star \star \star} \\
(0.04)\end{array}$ \\
\hline LGP & & & $\begin{array}{c}-0.20^{\star \star \star} \\
(0.04)\end{array}$ & $\begin{array}{c}-0.21^{\star \star \star \star} \\
(0.04)\end{array}$ \\
\hline LUT & & & $\begin{array}{l}-0.00 \\
(0.06)\end{array}$ & $\begin{array}{l}-0.00 \\
(0.06)\end{array}$ \\
\hline LYD & & & $\begin{array}{c}-0.12^{\star} \\
(0.06)\end{array}$ & $\begin{array}{l}-0.12^{\star} \\
(0.06)\end{array}$ \\
\hline LGBO & $\begin{array}{c}0.00 \\
(0.00)\end{array}$ & $\begin{array}{c}0.00 \\
(0.00)\end{array}$ & $\begin{array}{c}0.00 \\
(0.00)\end{array}$ & $\begin{array}{c}0.00 \\
(0.00)\end{array}$ \\
\hline LNBH & $\begin{array}{c}-0.02^{\star \star} \\
(0.00) \\
\end{array}$ & $\begin{array}{c}-0.02^{\star \star} \\
(0.00) \\
\end{array}$ & $\begin{array}{c}-0.02^{\star \star} \\
(0.00)\end{array}$ & $\begin{array}{c}-0.01^{\star \star} \\
(0.00)\end{array}$ \\
\hline LENF & $\begin{array}{l}-0.00 \\
(0.00) \\
\end{array}$ & $\begin{array}{l}-0.00 \\
(0.00) \\
\end{array}$ & $\begin{array}{l}-0.00 \\
(0.00) \\
\end{array}$ & $\begin{array}{l}-0.00 \\
(0.00) \\
\end{array}$ \\
\hline Sabit & $\begin{array}{c}2.63^{\star \star \star} \\
(0.19)\end{array}$ & $\begin{array}{c}2.56^{\star \star \star} \\
(0.19)\end{array}$ & $\begin{array}{c}2.23 \star \star \star \\
(0.17)\end{array}$ & $\begin{array}{c}2.18^{\star \star \star} \\
(0.18)\end{array}$ \\
\hline Hausman Testi & & 0.03 & & 0.00 \\
\hline Düzeltilmiş $R^{2}$ & 0.91 & 0.07 & 0.91 & 0.08 \\
\hline F-İstatistiği & 149.25 & 31.88 & 146.98 & 20.03 \\
\hline $\begin{array}{c}\text { Olasılik } \\
\text { (F-İstatistiği) }\end{array}$ & 0.0000 & 0.0000 & 0.0000 & 0.0000 \\
\hline
\end{tabular}

$\star \star \star . \star \star . \star$, sirasiyla $\% 1, \% 5 \mathrm{ve} \% 10$ anlam düzeyini ifade etmektedir.

SE (Sabit Etkili Model), RE (Rassal Etkili Model)

Rakamlar katsayı değerlerini, parantez içerisindeki rakamlar standart hatayı göstermektedir.

Bağımlı değişken: Savunma Harcamalarının GSYH içindeki yüzdesinin doğal logaritması.

Birinci model üzerinden yapılan analize göre, sabit ve rassal etkili sonuçlar, ekonomik özgürlükler ana endeksi ile savunma harcamaları arasında \%1 düzeyinde anlamlı ilişki olduğunu göstermektedir. Her iki sonuç için F-istatistik değeri anlamlı, düzeltilmiş $\mathrm{R}^{2}$ değerleri sabit etkili model için 0.91, rassal etkili model için 0.07'dir. Rassal etkili model üzerinden yapilan Hausman testinin sonucu 0.03 olarak bulunmuş, bu değer \%5'den küçük olduğu için daha önce ifade edildiği gibi sabit etkili modelin sonuçları dikkate alınmıştır. 
Sabit etkili model sonuçlarına göre, ekonomik özgürlükler ana endeksindeki \%1'lik artış, savunma harcamalarının GSYH içerisindeki yüzdesinde $\% 1,13$ oranında azalışa neden olabilir.

Düzeltilmiş $\mathrm{R}^{2}$ değerine göre, bağımlı değişken olan savunma harcamalarının GSYH içerisindeki yüzdesindeki değişimlerin \%91'i modelde yer alan bağımsız değişkenler tarafından açıklanmaktadır.

Birinci modele ilişkin sabit ve rassal etkili: Kalıntı (Residual), Gerçek değer (Actual) ve Kestirilmiş değer (Fitted) Grafikleri Şekil 2'de verilmiştir. Şekil 2.'ye göre sabit etkili modelin gerçek değer ve kestirilmiş değerler birbiri ile oldukça uyumludur. $\mathrm{Bu}$ uyum modelin tahmin performansının yüksek olduğunu göstermektedir.

\section{Şekil 2: Birinci Modele ilişkin Sabit ve Rassal Etkili: Kalıntı (Residual), Gerçek Değer (Actual) ve Kestirilmiş Değer (Fitted) Grafikleri}

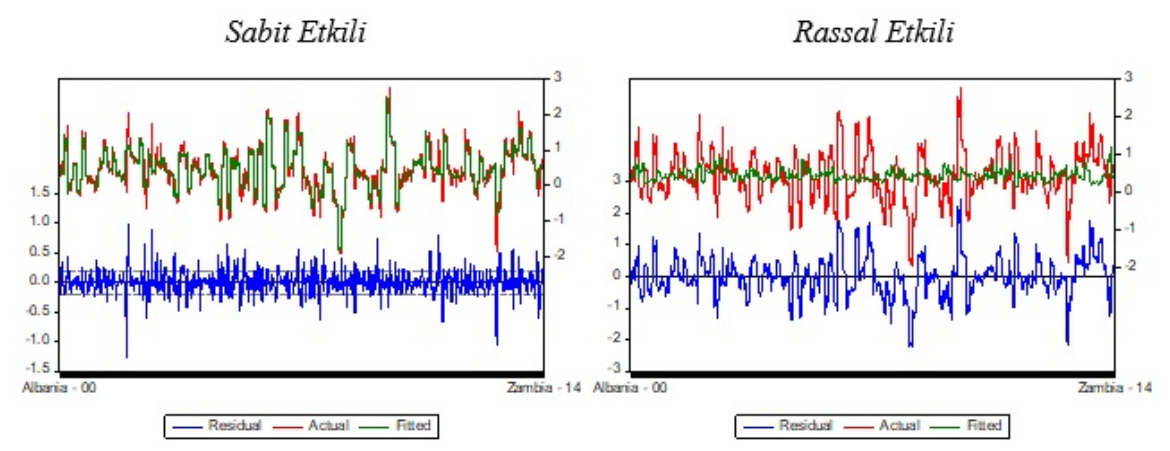

Ekonomik özgürlükler ana endeksi ve savunma harcamaları arasındaki ilişkiyi görmek için kurulan modele ilişkin yapılan inceleme sonucunda anlamlı ilişki bulunmuştur. Savunma Harcamaları-Ekonomik Özgürlükler Ana Endeksi arasındaki ilişkiye ait analiz sonuçları, "Ekonomik özgürlüklerde meydana gelen artışlar savunma harcamaları üzerinde azalışlara neden olabilir." biçiminde ifade edilmiş olan I. Hipotezi desteklemiştir.

İkinci model ekonomik özgürlükler endeksinin 5 ana bileşeni ile savunma harcamaları arasındaki ilişkinin kontrol değişkenleri ile beraber 
yapılan analizini göstermektedir. Analiz sonuçlarına göre sabit ve rassal etkili sonuçlar, savunma harcamalarının;

i. Devletin faaliyet alanının genişliği, hukuki yapı ve mülkiyet hakları ve güçlü paraya erişim ana başlığı ile \%1 düzeyinde anlamlı ilişki olduğunu,

ii. Kredi, işgücü ve iş dünyası konusunda yasal düzenlemeler ana bileşeni ile arasında \%10 düzeyinde anlamlı ilişki olduğunu

iii. Uluslararası ticaret serbestisi ana bileşeni ile arasında anlamlı bir ilişkinin olmadığını göstermektedir.

Her iki sonuç için de F-istatistik değeri anlaml, düzeltilmiş $\mathrm{R}^{2}$ değerleri sabit etkili model için 0.91 , rassal etkili model için 0.08 'dir. Rassal etkili model üzerinden yapılan Hausman testinin sonucu 0,00 olarak bulunmuş bu değer \%5'den küçük olduğu için daha önce ifade edildiği gibi sabit etkili modelin sonuçları dikkate alınmıştır. Sabit etkili model sonuçlarına göre:

i. Devletin faaliyet alanının genişliğindeki \%1'lik artış, savunma harcamalarının GSYH içerisindeki yüzdesinde $\% 0,34$ oranında azalışa neden olabilir.

ii. Hukuki yapı ve mülkiyet haklarındaki \%1'lik artış, savunma harcamalarının GSYH içerisindeki yüzdesinde $\% 0,27$ oranında azalışa neden olabilir.

iii. Güçlü paraya erişimdeki \%1'lik artış, savunma harcamalarının GSYH içerisindeki yüzdesinde $\% 0,20$ oranında azalışa neden olabilir.

iv. Kredi, işgücü ve iş dünyası konusunda yasal düzenlemelerdeki \%1'lik artış, savunma harcamalarının GSYH içerisindeki yüzdesinde $\% 0,12$ oranında azalışa neden olabilir.

Düzeltilmiş $\mathrm{R}^{2}$ değerine göre, bağımlı değişkendeki değişimlerin \%91'i modelde yer alan bağımsız değişkenler tarafından açıklanmaktadır. İkinci modele ilişkin sabit ve rassal etkili: Kalıntı (Residual), Gerçek değer (Actual) ve Kestirilmiş değer (Fitted) Grafikleri Şekil 3.'te verilmiştir. Şekil 3'e göre sabit etkili modelin gerçek değer ve kestirilmiş değerleri birbiri ile oldukça uyumludur. Bu uyum modelin tahmin performansının yüksek olduğunu göstermektedir. 


\section{Şekil 3: İkinci Modele ilişkin Sabit ve Rassal Etkili: Kalıntı (Residual), Gerçek Değer (Actual) ve Kestirilmiş Değer (Fitted) Grafikleri}

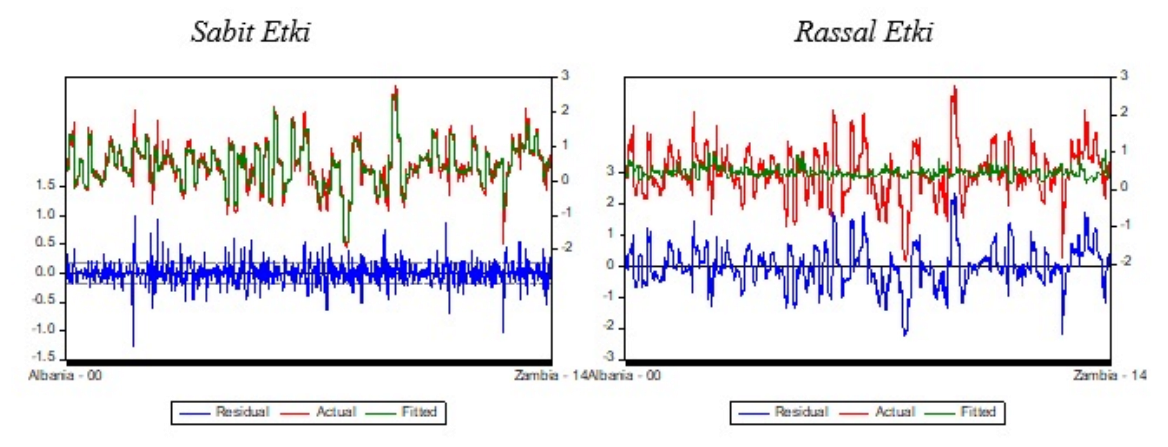

Ekonomik özgürlükler ana endeksleri ve savunma harcamalarının arasındaki ilişkiyi görmek için oluşturulan Model 2 üzerinden yapılan analizlere göre:

Devletin faaliyet alanının genişliği ile savunma harcamaları arasındaki ters yönlü ve anlamlı ilişki, hükümet harcamalarının ve vergi gelirlerinin azalması durumunda kamu harcamalarının da azalması olarak yorumlanabilir ve savunma harcamaları da bu durumda azalış gösterebilir. Tersi durumda hükümet harcamalarının toplamdaki payı ve marjinal vergi oranlarının artışı savunma harcamalarına ayrılan kaynağı artırabilir. $\mathrm{Bu}$ açıdan bakıldığında devletin artan gelirini kamu harcamaları arasında dağıtması ile savunma harcamalarının payının da artabilecek olması muhtemeldir.

Hukuki yapı ve mülkiyet hakları ile savunma harcamaları arasındaki ters yönlü ve anlamlı ilişki, düzenli işleyen hukuk sistemlerinin suçu caydırıcı yönü düşünüldüğünde iç savunmaya ayrılan kaynakları azaltabileceği olarak düşünülebilir. Her ne kadar mülkiyet haklarının korunması ve polise güven alt başlıkları savunma harcamalarına ayrılan kaynaklarla mümkün olabilse de buradan çıkabilecek sonuç bu kaynak aktarımlarının hukukun düzenli işleyişi sonucunda meydana gelen caydırıcılıktan büyük olmadığı yönündedir. Hukukun üstünlüğünün azalış gösterdiği durumlarda savunma harcamalarının artmasından, hukukun sağlayamadığı düzenin savunma harcamalarının arttırılmasıyla sağlanabileceği şeklinde bir çıkarım yapılabilir. 
Güçlü paraya erişim ile savunma harcamaları arasındaki ters yönlü ve anlamlı ilişkiyi enflasyonu düşük, alternatif para birimlerinin kullanıldığı ve yabancı para cinsinden banka hesabı açmanın kolay olduğu ülkelerin savunma harcamalarını azalttığı olarak yorumlamak mümkündür. Endeks içerisinde bu ülkeler daha yüksek puanlanmaktadır.

Söz konusu ilişkinin ters yönlü olduğu düşünüldüğünde, enflasyon odaklı yaklaşımla, enflasyon artışlarının endeks değerini düşürdüğü dolayısıyla savunma harcamalarında artış meydana getirdiği düşünülebilir. Endeks değerinin tek başına enflasyon odaklı belirlenmemesi nedeniyle bu dolaylı etkinin diğer parametrelere de bağlı olduğunu unutmamak gerekmektedir. Analizde kontrol değişkeni olarak eşitliğe dâhil edilen enflasyonun savunma harcamaları ile anlamlı bir ilişki göstermemesi bu bağ 1 desteklemektedir.

Kredi, işgücü ve iş dünyası konusunda yasal düzenlemeler ile savunma harcamaları arasındaki ters yönlü ve anlamlı ilişki ekonomik büyümenin savunma harcamaları üzerinde yaratacağı etki açısından ele alındığında, yasal düzenlemelerle ekonomi üzerinde meydana gelecek pozitif büyüme etkileri savunma harcamaları üzerinde azalış meydana getirebileceği gibi, düzenlemeler sonucunda ortaya çıkabilecek ekonomi üzerindeki negatif etkilerin savunma harcamalarında artış olarak sonuçlanması çıkarımı yapılabilir.

Bireylerin güvenli çalışmasını sağlayacak düzenlemelerin de toplumun huzurlu yapısına katkı sağlayarak yine bu bağlamda yurtiçi savunmaya ayrılan payın azalması yoluyla savunma harcamaları genelinde de azalış meydana getirebilmesi mümkündür.

Yasal düzenlemelerle birlikte piyasaya girişlerin kolaylaşmasının, ülkelerarası ticaretin gelişmesi yoluyla savunma harcamalarında azalış meydana getirebileceği düşünülmektedir. Fakat uluslararası ticaret serbestisine ilişkin kurulan V. hipotezi işaret eden bu durumu destekleyecek bulgulara rastlanmamıştır. Tablo 14, analize ilişkin özet sonuçları göstermektedir. 
Tablo 14: Analize İlişkin Özet Sonuçlar

\begin{tabular}{lcc}
\hline \multicolumn{1}{c}{ Bağımsız Değişken } & Analiz Kodu & \multicolumn{1}{c}{ İlişkinin Türü } \\
\hline $\begin{array}{l}\text { Ekonomik Özgürlük Genel Endeksi } \\
\text { Devletin Faaliyet Alanının Genişliği: }\end{array}$ & LEO & Anlamlı Ters Yönlü İlişki \\
$\begin{array}{l}\text { Harcamalar, Vergiler ve Girişimler } \\
\text { Hukuki Yapı ve Mülkiyet Hakları }\end{array}$ & LDG & Anlamlı Ters Yönlü İlişki \\
Güçlü Paraya Erişim & LMH & Anlamlı Ters Yönlü İlişki \\
Uluslararası Ticaret Serbestisi & LGP & Anlamlı Ters Yönlü İlişki \\
$\begin{array}{l}\text { Kredi, İsgücü ve İş Dünyası } \\
\text { Konusunda Yasal Düzenlemeler }\end{array}$ & LYD & Anlamlı İlişki Yoktur \\
\hline
\end{tabular}

Bağımlı Değişken: Savunma Harcamaları

\section{Sonuç}

Çalışmada, savunma harcamaları ile ekonomik özgürlükler arasındaki ilişki Fraser Enstitüsü'nün ekonomik özgürlükler endeksinden seçilen 110 ülkenin 2000-2014 yılları arasındaki verileriyle panel veri analiziyle ampirik olarak analiz edilmiştir. Analizde savunma harcamalarının belirleyicisi olarak savunma harcamalarının GSYH içerisindeki yüzdelik payı, ekonomik özgürlüklerin belirleyicisi olarak Fraser Enstitüsü'nün genel ekonomik özgürlükler endeksi ve 5 ana bileşeni seçilmiştir.

Analizin sonuçları, genel ekonomik özgürlükler endeksi ve savunma harcamaları ilişkisini araştıran ilk modelin sonuçlarının anlamlı ve negatif yönlü olduğunu göstermiştir. Ekonomik özgürlüklere ilişkin beş ana bileşenin savunma harcamaları ile ilişkisinin incelendiği ikinci modele göre, Devletin Faaliyet Alanının Genişliği, Hukuki Yapı ve Mülkiyet Hakları, Güçlü Paraya Erişim ve Kredi, İşgücü ve İş Dünyası Konusunda Yasal Düzenlemeler ile savunma harcamaları arasında negatif yönlü ve anlamlı ilişkiye rastlanırken, Uluslararası Ticaret Serbestisi alt başlığının savunma harcamaları ile istatistiksel olarak anlamlı bir ilişkisi tespit edilememiştir.

Ekonomik özgürlüklerin savunma harcamalarını azaltabileceği yönünde elde edilen bulgular, ülkelerin ekonomik olarak daha özgür olma çabalarının savunma harcamalarında azalışlar meydana getirebileceğini göstermektedir. Bu bağlamda savunma harcamaları yüksek olan ülkelerin ekonomik özgürlüklerini arttırıcı adımlarla savunma harcamalarını azaltabileceği öngörülmektedir. 
Endeksin ana başlıklarından Devletin Faaliyet Alanının Genişliği devletin ekonominin içerisindeki yerine vurgu yapmaktadır. Devletin ekonomi içerisindeki büyüklüğünün azalması daha yüksek bir özgürlük düzeyini, artması ise daha düşük bir özgürlük düzeyini ifade etmektedir. Analiz sonuçlarına göre savunma harcamalarıyla negatif yönlü ilişkisi bulunan Devletin Faaliyet Alanının Genişliğinin, kamu tüketimi ve vergi oranlarındaki azalışları hedefleyen ana bileşenlerinin etkisiyle bu sonuca ulaşıldığı, gelirde meydana gelen azalışların bir harcama kalemi olan savunma harcamalarına da etki ettiği düşünülmektedir. Ülkelerin ekonomik özgürlük yolunda atacağı adımlarda bu durumu göz önünde bulundurmaları, savunma harcamalarının azalıs göstermesinin daha büyük problemlere yol açacağı bazı ülkelerde bu alandaki adımların kontrollü atılması gerektiği düşünülmektedir.

Hukuki yapı ve mülkiyet hakları ana bileşeninin savunma harcamaları ile olan negatif yönlü ilişkisi sonucundan, bu ana bileşenin suçu hukuki olarak caydırma yönünün savunmaya ayrılan kaynağı azaltabileceği çıkarımı yapılabilir. Hukuki yapıda yapılacak iyileştirme ve düzenlemelerle daha özgür bir ekonomi yaratırken kamu harcamaları içinde önemli bir yere sahip olan savunma harcamalarında da azalmaya neden olabileceğini yapılabilecek bir diğer çıkarımdır. Bu azalmanın yarattığı kaynak fazlası da diğer harcama kalemlerine aktarılarak daha verimli kullanılabilecektir.

Güçlü paraya erişimde enflasyonu düşük, alternatif para birimlerinin kullanıldığı ve yabanc1 para cinsinden banka hesabı açmanın kolay olduğu ülkeler endeks içerisinde daha yüksek puanlanmaktadır. Ülkelerin enflasyon oranlarındaki artışların, güçlü para ve savunma harcamaları arasındaki negatif yönlü ilişki nedeniyle savunma harcamalarında da artış meydana getirebileceği düşünülmektedir. Her ne kadar kontrol değişkeni olarak analize dâhil edilen enflasyon oranının savunma harcamaları ile anlamlı ilişkisinin olmadığı sonucuna varılsa da güçlü paraya erişim ana başlığını oluşturan alt başlıkların sadece enflasyon oranına bağlı olmadığ düşünüldüğünde söz konusu bu artışların nedeninin sadece alım gücündeki azalıştan kaynaklanmadığı düşünülebilir. Dolayısıyla ülkelerin ekonomik özgürlükleri arttırıcı yolda enflasyonlarını düşürücü politikalar izlemesi alım gücünde meydana gelen artışlar ve diğer alt başlıkların etkisiyle savunma harcamalarının GSYH içerisindeki oranını azaltabilir. 
Kredi, işgücü ve iş dünyası konusunda yasal düzenlemeler ana bileşeninin savunma harcamaları ile olan negatif ilişkisi büyümeye yapacağı pozitif veya negatif katkı açısından düşünülebilir. Ülkelerin büyüme yolunda reform olarak ele alınabilecek bu yöndeki değişimlerin de savunma harcamalarında negatif yönlü değişim meydana getirebileceği göz önünde bulundurulmalıdır. Birey açısından, bireylerin daha güvenli çalışma ortamlarına sahip olması çatışmayı azaltabilir. Çatışma da meydana gelen azalmasının savunma harcamaları üzerinde azalışa neden olabileceği sonucu da bu bağlamda olumlu bir gelişme olarak düşünülmektedir.

Endeksin uluslararası ticaret serbestisi ana bileşeninin savunma harcamaları ile ilişkisine rastlanamamıştır. Oluşturulan hipotezlerde özellikle uluslararası ticaret serbestisinin, ülkeler arasındaki ticaretin gelişmesi sonucunda savunma harcamalarında azalış meydana getirebileceği düşünülmüş ancak destekleyici bir sonuca ulaşılamamıştır.

Çalışmada elde edilen bulgular, genel ekonomik özgürlük endeksi ve ana bileşenlerinin savunma harcamaları üzerinde etkisinin olabileceği yönündedir. Ekonomik özgürlüklerin, çatı̧̧madan kaçınma ve savunma harcamaları üzerinde azaltıcı etki sağlayabileceği olgusu ülkelerin kalkınmasına katkı sağlayabilir. Fakat ekonomik özgürlükler yönünde atılacak adımların savunma gibi önemli bir harcama kalemini azaltabilecek etki göstermesi her ülke için olumlu olmayabilecektir. Başka etkenlere dayalı yüksek savunma harcamalarına sahip ülkelerin ekonomik özgürlük yolunda ilerleyeceği patikayı doğru seçmeleri önerilmektedir.

\section{Summary}

The pursuit of a new approach to growth alternative to today's economic growth models leads countries to reformation, reconstruction of their institutions, and self-reflection. Liberalization, which is defined as economic freedoms, arises as one of the pathways that take countries to economic growth.

The relationship between defense expenditures and economic freedoms has a common ground due to their impact on economic growth. If one considers that this common ground is one of the main problems of the economy, the analysis of this relationship gains the utmost importance. 
In the framework of the argument that places economic freedoms in the center of economic growth, defense is the primary role of the state. The position of the state in this regard is the rule of law and the provision of certain public services. Thus, this study aims to investigate the relationship between defense expenditures and the parameters that constitute economic freedoms. This relationship was investigated using data for 110 countries covered in the index of economic freedoms of the Fraser Institute for the years 2000-2014 by employing the panel-data analysis technique.

For this purpose, the hypotheses of this study are as follows:

Hypothesis I: Increases in economic freedoms have a negative impact on defense expenditures.

Hypothesis II: Increases in the field of state activity have a negative impact on defense expenditures.

Hypothesis III: Increases in the rule of law and property rights have a negative impact on defense expenditures.

Hypothesis IV: Increases in access to strong currency have a negative impact on defense expenditures.

Hypothesis V: Increases in free international trade have a negative impact on defense expenditures.

Hypothesis VI: Increases in regulations have a negative impact on defense expenditures.

Various tasks have been assigned to the state in the framework of economic freedoms. Adam Smith lists the three main duties of both civilized and primitive states as defense, justice, and public affairs. Although it varies by the level of development of the society, these three pillars also constitute public services.

Smith who identifies defense as the primary obligation of the state indicates that the cost of using military force to protect the society from other independent communities during the war would be different than maintaining it during peace. In the pathway to civilization, he remarks that the cost of protecting the society, especially in the aftermath of a war or during peace, is higher (Smith, 2012: 691-708).

The idea that increases in economic freedoms generate economic growth within the basic dynamics of classical thought is distilled by the idea 
that democracy, economic cooperation, and international law constitute the foundation of perpetual peace by Kant (1795) in the same years. Later, Schumpeter (1919) established a link between economic freedoms and conflict by indicating that the transition to the industrialized capitalist production techniques would end the war.

This study estimates the relationship between defense expenditures and the indices and their sub-categories of economic freedoms by controlling for other factors. In this framework, two main models were used in the study.

In the first model, the relationship between defense expenditures and economic freedoms was analyzed along with other control variables. In the second model, the relationship between defense expenditures and the five main components of the economic freedoms index were examined along with other control variables.

The results of the first model indicate a negative and statistically significant relationship between defense expenditures and economic freedoms. According to the results of the second model, there is a negative and statistically significant relationship between defense expenditures and the size of government, legal systems and property rights, sound money, and regulation of credit, labor, and business. Findings do not provide evidence for a statistically significant relationship between defense expenditures and the component of the index for freedom to trade internationally.

Findings regarding the negative impact of economic freedoms on defense expenditures indicate that nations' efforts to increase freedoms in the economy may reduce defense expenditures. The policy implication is that countries that have high defense expenditures can reduce it through public policies that improve their economic freedom.

The notion that economic freedoms might increase conflict-avoidance and reduce defense expenditures can contribute to countries' development. However, not in all countries, steps taken to improve economic freedoms might result in a reduction in defense expenditures, which is an important expense item. It is recommended that countries that have high defense expenditures due to other factors should choose a pathway to economic freedom that is right for themselves. 
Mehmet Samet ERDEM - Selami SEZGIN

\section{Çatışma Beyanı:}

Araştrmanin yazarları olarak herhangi bir çıkar çatışma beyanımı bulunmamaktadir.

\section{Destek ve Teşekkür Beyan:}

$\mathrm{Bu}$ çalı̧̧manin hazrrlanmasinda hiçbir diş finansmandan yararlanılmamıştr. Çallsma Eskişehir Osmangazi Üniversitesi Sosyal Bilimler Enstitüsü İktisat Anabilim dalında Prof. Dr. Selami SEZGIN danısmanlığrnda hazrrlanan Dr. Öğr. Üyesi Mehmet Samet ERDEM'e ait "Savunma Ekonomisi

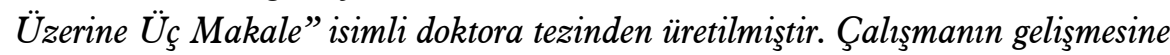
ve sonuçlanmasina eşsiz katkllar sunan bütün hocalarmma teşekkür ederim.

\section{Araştırmacıların Katkı Oranı Beyanı:}

İkinci yazarı çalışmanın danışmanı olup araştrmanın hazırlanmasinda birinci yazarnn katkı oranı $\% 60$, ikinci yazarnn katkı oranı $\% 40$ 'trr.

\section{Kaynakça}

Kitaplar

BEACH, William W. and DAVIS Gareth, The Index Of Economic Freedom And Economic Growth, The Heritage Foundation, Washington, 1997.

CAMERON, A. Colin and TRIVERDI, Pravin. K. Microeconometrics Methods and Applications, Cambridge University Press, New York, 2005.

HSIAO, Cheng Analysis of Panel Data. Cambridge University Press, Second Edition, United Kingdom, 2003.

KANT, Immanuel, Perpetual Peace: A Philosophical Essay, Cambridge University Press, Cambridge, 1795, Vol. 1903.

MILLER, Terry and HOLMES, Kim R. 2011 Index of Economic Freedom, The Heritage Foundation, The Wall Street Journal, New York, NY 10281, 2011.

SCHUMPETER, Joseph A., The Sociology of Imperialism, In Imperialism \& Social Classes, 3-98 Cleveland, World Publishing, 1919.

SMITH, Adam, The Wealth of Nations, Wordsworth Edition, London, 2012.

STEIN, Arthur. A. The Nation at War, Baltimore, MD: Johns Hopkins Univ. Press, 1980.

Makaleler ve Raporlar

BARBIERI, Katherine "Economic Interdependence: A Path to Peace or a Source of Interstate Conflict?", Fournal of Peace Research, 1996. 33(1), p. 29-49.

BARRO, Robert. J., "Democracy and Growth”, Fournal of Economic Growth, 1996, 1(1), p.1-27.

BEŞKAYA, Ahmet ve KOÇ, Asuman, "Ekonomik Büyüme ve Kalkınmada Ekonomik Özgürlüklerin Rolü ve Önemi”, Liberal Düsünce, 2006, 43, ss.43-74.

BURGESS, Cara, BEAULIER, Scott et al.," Economic Freedom and Conflict: An Empirical Note", Fournal of Economics and Economic Education Research, 2009 10(3), p. 75-83. 
CAPRA, James. R., “The National Defense Budget and its Economic Effects”, Federal Reserve Bank of New York Q. Rev, 1981, 6, p. 21-31.

CARLSSON, Fredrik and LUNDSTRÖM, Susanna, "Economic Freedom and Growth: Decomposing the Effects", Public Choice, 2002, 112(3-4), p. 335-344.

CEBULA, Richard. J., Clark, J. R. et al.," The Impact of Economic Freedom on Per Capita Real GDP: A Study of OECD Nations", fournal of Regional Analysis $\mathcal{G}$ Policy, 2013, 43(1), p.34-41.

DUNNE, J., Paul, "Economic Effects of Military Expenditure in Developing Countries", Gleditsch, N.P., Bjerkholt, O., Cappelen, A., Smith, R. and Dunne, J.P. (Ed.) The Peace Dividend (Contributions to Economic Analysis, Vol. 235), Emerald Group Publishing Limited, Bingley, 1996, pp. 439-464.

DZIDROV, Misko, MIRAKOPCSKI, Dejan, et al.” Relationship between Economic Freedom and Conflict in the Balkan Region" International Fournal of Scientific $\mathcal{E}$ Engineering Research, 2013, 4(10), p. 433-436.

ERDAL, Fuat and YENIPAZARLI, Asl,, "Which Economic Freedoms Contribute Income Per Capita? Are Results Sensitive to the Indicators and the Estimation Methods?", Emerging Markets Finance and Trade, 2013, 49(5), p. 130-147.

FABRO, Gema and AIXALÁ, Jose, "Direct and Indirect Effects of Economic and Political Freedom on Economic Growth", Fournal of Economic Issues, 2012, 46(4), p. 1059-1080.

GARTZKE, Erik, "Economic Freedom of the World 2005", Annual Report, The Fraser Institute, Vancouver, Canada, 2005.

GWARTNEY, James and LAWSON, Robert "The Concept and Measurement of Economic Freedom", European Fournal of Political Economy, 2003, 19.3, 405-430.

GWARTNEY, James. D., LAWSON, Robert et al. "Economic Freedom of the World 2016" Annual Report, The Fraser Institute. Canada, 2016.

GWARTNEY, James. D., LAWSON, Robert. A. et al., "Economic Freedom and the Environment for Economic Growth", Fournal of Institutional and Theoretical Economics (FITE)/Zeitschrift für die gesamte Staatswissenschaft, 1999, 155(4), p. 643-663.

HAMILTON, Earl. J. "The Role of War in Modern Inflation." Fournal of Economy History, 1977, 37(1), p. 13-19.

HSIAO, Cheng "Why Panel Data?", The Singapore Economic Review, 2005, 50(2), 143154, p. 146-148.

IM, Kyung. S., PESARAN, M. Hashem et al., "Testing for Unit Roots in Heterogeneous Panels", Fournal of Econometrics, 2003, 115(1), p. 53-74.

KAUFMAN, R. F., "The Pentagon Stokes Inflation", The Nation, 1972, (May 1), p. 555-558.

LOONEY, Robert and MCNAB, Robert. M., "Can Economic Liberalization and Improved Governance Alter the Defense-Growth Trade-Off?”, Review of Financial Economics, 2008, 17(3), p. 172-182.

MELMAN, Seymour, "The Defense Economy: Conversion of Industries and Occupations to Civilian Needs", Praeger Publishers, 1970, New York.

MICHAEL. W. Browne, "Asymptotically Distribution Free Methods for the Analysis of Covariance Structures". British Fournal of Mathematical and Statistical Psychology, 1984, 37, p. 62-83.

NELSON, Michael. A. and SINGH, Ram. D., "Democracy, Economic Freedom, Fiscal Policy, and Growth in LDCs: A Fresh Look", Economic Development and Cultural Change, 1998, 46(4), p. 677-696.

PANAHI, Hossein, ASSADZADEH, Ahmad. et al., "Economic Freedom and Economic Growth in MENA Countries", Asian Economic and Financial Review, 2014, 4(1), 105-116. 
PÉREZ-MORENO, Salvador and ANGULO-GUERRERO, Maria. J., "Does Economic Freedom Increase Income Inequality? Evidence from the EU Countries", fournal of Economic Policy Reform, 2016, 19(4), p. 327-347.

PHILLIPS, Peter CB and PERRON, Pierre, "Testing for a Unit Root in Time Series Regression.” Biometrika, 1988, 75.2, p. 335-346.

ROSH, Robert. M., "Third World Militarization: Security Webs and the States They Ensnare", Fournal of Conflict Resolution, 1988, 32(4), p. 671-698.

RUMMEL, Rudolph. J., "Libertarianism and International Violence", fournal of Conflict Resolution, 1983, 27(1), p. 27-71.

SAUNORIS, James. W. and SAJNY, Aishath, "Entrepreneurship and Economic Freedom: Cross-Country Evidence from Formal and Informal Sectors", Entrepreneurship \& Regional Development, 2017, 29(3-4), p. 292-316.

TURES, John A.," Economic Freedom and Conflict Reduction: Evidence from the 1970s, 1980s, and 1990s.", Cato Fournal, 2002, 22(3), p. 533-542.

YILDIRIM, Julide and SEZGIN, Selami, "Democracy and Military Expenditure: A Cross-Country Evidence", Transition Studies Review, 2005, 12(1), p. 93-100.

İnternet Kaynakları

FRASER INSTITUTE, https://www.fraserinstitute.org/(Erişim Tarihi: 18 Şubat 2017).

Tezler

GÜNANA, Tayfun, The Relationship Between Defense Spending and Inflatıon: An Emprical Analysis for Turkey, Master of Business Administration Thesis, The Institute of Economics and Social Sciences of Bilkent University, Ankara. 2004.

RIDDERSTEDT, Ivan, Economic Freedom and Entrepreneurship: Conflicting Evidence, Bachelor Thesis, Södertörn University School of Social Sciences, Stockholm, 2014. 